\title{
Structural characterization of vanadium oxide catalysts supported on nanostructured silica SBA-15 using X-ray absorption spectroscopy
}

\author{
Anke Walter ${ }^{1}$, Rita Herbert ${ }^{2}$, Christian Hess ${ }^{2,3}$, Thorsten Ressler ${ }^{1 *}$
}

\begin{abstract}
The local structure of vanadium oxide supported on nanostructured $\mathrm{SiO}_{2}\left(\mathrm{~V}_{\mathrm{x}} \mathrm{O}_{\mathrm{y}} / \mathrm{SBA}-15\right)$ was investigated by in situ X-ray absorption spectroscopy (XAS). Because the number of potential parameters in XAS data analysis often exceeds the number of "independent" parameters, evaluating the reliability and significance of a particular fitting procedure is mandatory. The number of independent parameters (Nyquist) may not be sufficient. Hence, in addition to the number of independent parameters, a novel approach to evaluate the significance of structural fitting parameters in XAS data analysis is introduced. Three samples with different $V$ loadings (i.e. 2.7 wt \%, 5.4 wt \%, and 10.8 wt \%) were employed. Thermal treatment in air at $623 \mathrm{~K}$ resulted in characteristic structural changes of the $\mathrm{V}$ oxide species. Independent of the $V$ loading, the local structure around $V$ centers in dehydrated $\mathrm{V}_{\mathrm{x}} \mathrm{O}_{\mathrm{y}} / \mathrm{SBA}-15$ corresponded to an ordered arrangement of adjacent $\mathrm{V}_{2} \mathrm{O}_{7}$ units. Moreover, the $\mathrm{V}_{2} \mathrm{O}_{7}$ units were found to persist under selective oxidation reaction conditions.
\end{abstract}

\section{Background}

Mixed transitions metal oxides (e.g. MoVNbTe oxides) are active in selective oxidation of propane to acrylic acid. In contrast to various binary oxides (e.g. $\mathrm{MoO}_{3}$ or $\mathrm{V}_{2} \mathrm{O}_{5}$ ), these mixed oxides exhibit a much higher selectivity. However, the origin of the promoting effect of, for instance, vanadium in mixed oxides is largely unknown. Hence, model systems are sought which enable conclusions on structure activity relationships of individual metal centers in active catalysts. For that, supported metal oxides possess two major advantages over bulk oxides. First, particular metal oxide structures which are not readily available for investigations under reaction conditions can be stabilized and studied on suitable support materials [1]. Second, dispersed supported metal oxides simplify correlating the local structure around the metal centers with their catalytic performance. Distinguishing active metal centers at the surface from metal centers in the bulk of conventional oxide catalysts is no longer required.

$\mathrm{V}_{\mathrm{x}} \mathrm{O}_{\mathrm{y}}$ supported on SBA-15 (nanostructured $\mathrm{SiO}_{2}$ ) [2] constitutes a suitable model system to investigate the

\footnotetext{
* Correspondence: thorsten.ressler@tu-berlin.de

'Institut für Chemie, Technische Universität Berlin, Strasse des 17. Juni 135, 10623 Berlin, Germany
}

role of vanadium during selective oxidation catalysis [3-6]. Structural characterization of $\mathrm{V}_{\mathrm{x}} \mathrm{O}_{\mathrm{y}}$ supported on $\mathrm{SiO}_{2}$ has been subject of many spectroscopic studies including IR [[7-9], XPS [6,10,11], Raman [10-15], UVVIS [11,13-16] and EXAFS [13,17-22]. A recent review of spectroscopic investigations and structural characteristics of various supported vanadium oxides has been presented by Weckhuysen and Keller [23]. It is assumed, that the structure of supported vanadium oxide depends on both amount of vanadium and degree of hydration [14]. Hence, most studies were performed on $\mathrm{V}_{\mathrm{x}} \mathrm{O}_{\mathrm{y}} / \mathrm{SiO}_{2}$ samples exhibiting low vanadium loading $(<10 \mathrm{wt} \%)$. At these loadings a monolayer of supported $\mathrm{V}_{\mathrm{x}} \mathrm{O}_{\mathrm{y}}$ species is assumed and crystalline $\mathrm{V}_{2} \mathrm{O}_{5}$ is not detectable. Under ambient conditions the structure of hydrated vanadium oxide supported on $\mathrm{SiO}_{2}$ resembles that of $\mathrm{V}_{2} \mathrm{O}_{5}[10,13,18]$. Thermal treatment in oxygen results in dehydration of the vanadium oxide species. This dehydrated state has been proposed to consist of isolated $\mathrm{VO}_{4}$ tetrahedrons bond to the $\mathrm{SiO}_{2}$ support $[13,17,24,25]$. However, $\mathrm{V}_{2} \mathrm{O}_{7}$ dimers or further extended structures supported on $\mathrm{SiO}_{2}$ have not been excluded [15]. In total, the structure of dehydrated vanadium oxide species supported on $\mathrm{SiO}_{2}$ remains under debate. 
XAS is particularly suitable to study supported catalysts under reaction conditions. The average valence, for instance, can be readily obtained by comparison with known reference compounds. Elucidating the geometric structure, however, is often more difficult. In the conventional approach theoretical XAFS scattering amplitudes and phases are calculated for a suitable model structure. Subsequently, a sum of theoretical XAFS functions is refined to the experimental data. Structural parameters like coordination numbers, nearest neighbor distances, and disorder parameters may be determined. However, more often than not, the number of potential parameters exceeds the number of "independent" parameters. The upper limit may be calculated from Fourier theory and must not be exceeded. Nonetheless, it appears that even refinements employing a much smaller number of freely varied parameters may yield ambiguous structural results. The often used Nyquist criteria may not be sufficient to deem a fitting procedure reliable. Basically, one pair of strongly correlated parameters suffices to render a seemingly good agreement between experimental data and theoretical model structure meaningless. While this case may be clearly indicated by the correlation matrix of the refinement, other pitfalls may be less obvious. Hence, procedure are sought that enable evaluating the significance of each fitting parameter individually.

Here, we have performed in situ XAS investigations of $\mathrm{V}_{\mathrm{x}} \mathrm{O}_{\mathrm{y}}$ supported on SBA-15 in the hydrated and dehydrated state. The same materials were already carefully characterized by several standard techniques (i.e. physisorption, TEM, IR, Raman, UV-Vis, and XPS) and the results of these studies have been described in Ref $[9,10,14]$. In particular, using UV-Vis and Raman spectroscopy, Hess et al. showed that the catalysts are similar to other systems previously described in the literature. However, the results obtained could not unequivocally determine the local structure around the $\mathrm{V}$ species on $\mathrm{SiO}_{2}$, as it was also the case in previous studies. Our approach focused on elucidating the local structure around the vanadium centers in the dehydrated state of $\mathrm{V}_{\mathrm{x}} \mathrm{O}_{\mathrm{y}}$-SBA-15 model catalysts with different vanadium loadings. A detailed XAFS data analysis, in particular of higher $\mathrm{V}-\mathrm{V}$ distances, was performed together with a detailed evaluation of the significance of the fitting parameters employed. This procedure permitted detailed conclusions on the extended local structure of the vanadium oxide species supported on SBA- 15.

\section{Results and discussion}

Local structure of dehydrated $\mathrm{V}_{\mathrm{x}} \mathrm{O}_{\mathrm{y}} / \mathrm{SBA}-15$ - Comparison to $\mathrm{V}$ oxide references

Characterization of pore structure and surface area, and optical spectroscopic investigations of the same model catalysts studied here have been previously described $[9,10,14]$. After surface functionalisation and ion exchange to introduce the $\mathrm{V}$ precursor, the materials were calcined at $823 \mathrm{~K}$ in air. Calcination results in decomposition of both precursor and functionalisation agent. Preparation, functionalisation, and thermal treatment also have been described in $\operatorname{Ref}[9,10,14]$. The authors stated that residuals of the functionalisation agent were no longer detectable (i.e. IR, Raman, UV-Vis, and XPS) in the material obtained. A brief summary of the $\mathrm{N}_{2}$ physisorption analysis described in Ref [10] is given in Table 1.

Here, we have performed a detailed XAFS investigation of samples with different $\mathrm{V}$ loadings in the hydrated and dehydrated state. In particular, we wanted to analyze the contribution of higher scattering shells to the XAFS signal and possibly reveal the presence of $\mathrm{V}$ nearest neighbors in the local structure of vanadium oxide species supported on $\mathrm{SiO}_{2}$. A detailed XAFS analysis of higher shells in the $\operatorname{FT}\left(\chi(k)^{*} k^{3}\right)$ has been largely neglected in the corresponding literature.

During thermal treatment of as-prepared hydrated $\mathrm{V}_{\mathrm{x}} \mathrm{O}_{\mathrm{y}} / \mathrm{SBA}-15$ in oxygen $(20 \%$ in $\mathrm{He})$ a loss of water and a distinct change in structure were observed. After thermal treatment dehydrated $\mathrm{V}_{\mathrm{x}} \mathrm{O}_{\mathrm{y}} / \mathrm{SBA}-15$ was cooled to $293 \mathrm{~K}$ in oxygen in He without exposure to air or water. No changes in XAFS spectra were observed during cooling. The EXAFS $\chi(k)^{*} \mathrm{k}^{3}$ of dehydrated $\mathrm{V}_{\mathrm{x}} \mathrm{O}_{\mathrm{y}} /$ SBA-15 with different $\mathrm{V}$ loadings are depicted in Figure 1 . The usable spectral ranged extended from $2.7 \AA$ through 11.0 A. The V K edge XANES spectra and the FT $(\chi(\mathrm{k})$ ${ }^{*} \mathrm{k}^{3}$ ) of dehydrated $\mathrm{V}_{\mathrm{x}} \mathrm{O}_{\mathrm{y}} / \mathrm{SBA}-15$ samples measured at $293 \mathrm{~K}$ are shown in Figure 2. $\mathrm{FT}\left(\chi(\mathrm{k}){ }^{*} \mathrm{k}^{3}\right)$ are not phase shift corrected. Thus, the distances in the $\mathrm{FT}\left(\chi(\mathrm{k})^{*} \mathrm{k}^{3}\right)$ are shifted by $\sim 0.4 \AA$ to lower values compared to crystallographic distances. Compared to vanadium oxide references, the overall XANES region of dehydrated $\mathrm{V}_{\mathrm{x}} \mathrm{O}_{\mathrm{y}} / \mathrm{SBA}-15$ resembled best those of $\mathrm{NH}_{4} \mathrm{VO}_{3}$, $\mathrm{Mg}_{2} \mathrm{~V}_{2} \mathrm{O}_{7}$, and $\mathrm{Na}_{3} \mathrm{VO}_{4}$ (Figure 3(a)). In the local structure of these references vanadium centers are tetrahedrally coordinated by four oxygen atoms. Compared to the XANES spectrum of dehydrated $\mathrm{V}_{\mathrm{x}} \mathrm{O}_{\mathrm{y}} / \mathrm{SBA}-15$, $\mathrm{NH}_{4} \mathrm{VO}_{3}$ and $\mathrm{Mg}_{2} \mathrm{~V}_{2} \mathrm{O}_{7}$ exhibit very similar pre-edge peak heights in their XANES spectra (i.e. 0.65). Conversely, the pre-edge peaks in the XANES of $\mathrm{Na}_{3} \mathrm{VO}_{4}$ and $\mathrm{Mg}_{3} \mathrm{~V}_{2} \mathrm{O}_{8}$ are much higher than that of dehydrated $\mathrm{V}_{\mathrm{x}} \mathrm{O}_{\mathrm{y}} /$ SBA-15 (Figure 3(a)).

In Figure 3(b) the $\mathrm{FT}\left(\chi(\mathrm{k}){ }^{*} \mathrm{k}^{3}\right)$ of $\mathrm{NH}_{4} \mathrm{VO}_{3}, \mathrm{Mg}_{2} \mathrm{~V}_{2} \mathrm{O}_{7}$, and $\mathrm{Na}_{3} \mathrm{VO}_{4}$ are compared to that of dehydrated $\mathrm{V}_{\mathrm{x}} \mathrm{O}_{\mathrm{y}} /$ SBA-15. The first V-O peak in the FT $\left(\chi(k) * k^{3}\right)$ at $\sim 1.4$ $\AA$ (not phase shift corrected) for all references shown corresponds to a $\mathrm{VO}_{4}$ tetrahedron in the respective structures. Apparently, the spectra of $\mathrm{NH}_{4} \mathrm{VO}_{3}$ and $\mathrm{Mg}_{2} \mathrm{~V}_{2} \mathrm{O}_{7}$ most closely resemble that of dehydrated 
Table $1 \mathbf{N}_{2}$ physisorption analysis of supported vanadium oxide samples.

\begin{tabular}{|c|c|c|c|c|c|c|}
\hline & $\begin{array}{l}\text { Vanadiu } \\
\text { (wt \%) }\end{array}$ & $\begin{array}{l}\mathrm{g} \text { on SBA-15 } \\
\mathrm{V} \text { atoms } / \mathrm{nm}^{2}\end{array}$ & $(\mathrm{mmol} / \mathrm{g})$ & $\begin{array}{l}S_{B E T} \\
\left(m^{2} / g\right)\end{array}$ & $\begin{array}{l}d_{p} \\
(n m)\end{array}$ & $\begin{array}{l}V_{p} \\
(\mathrm{~mL} / \mathrm{g})\end{array}$ \\
\hline SBA-15 & - & - & - & 897 & 7.0 & 1.1 \\
\hline 2.7 wt \% V/SBA-15 & 2.7 & 0.7 & 0.53 & 445 & 6.7 & 0.5 \\
\hline 5.4 wt \% V/SBA-15 & 5.4 & 1.4 & 1.05 & 440 & 6.6 & 0.5 \\
\hline 10.8 wt $\%$ V/SBA-15 & 10.8 & 4.7 & 2.12 & 273 & 5.5 & 0.3 \\
\hline
\end{tabular}

Vanadium loading, surface area $\left(S_{B E T}\right)$, pore diameter $\left(d_{p}\right)$, and pore volume $\left(V_{P}\right)$ of SBA-15 and vanadium oxides supported on SBA-15. Details have been presented in Ref [10].

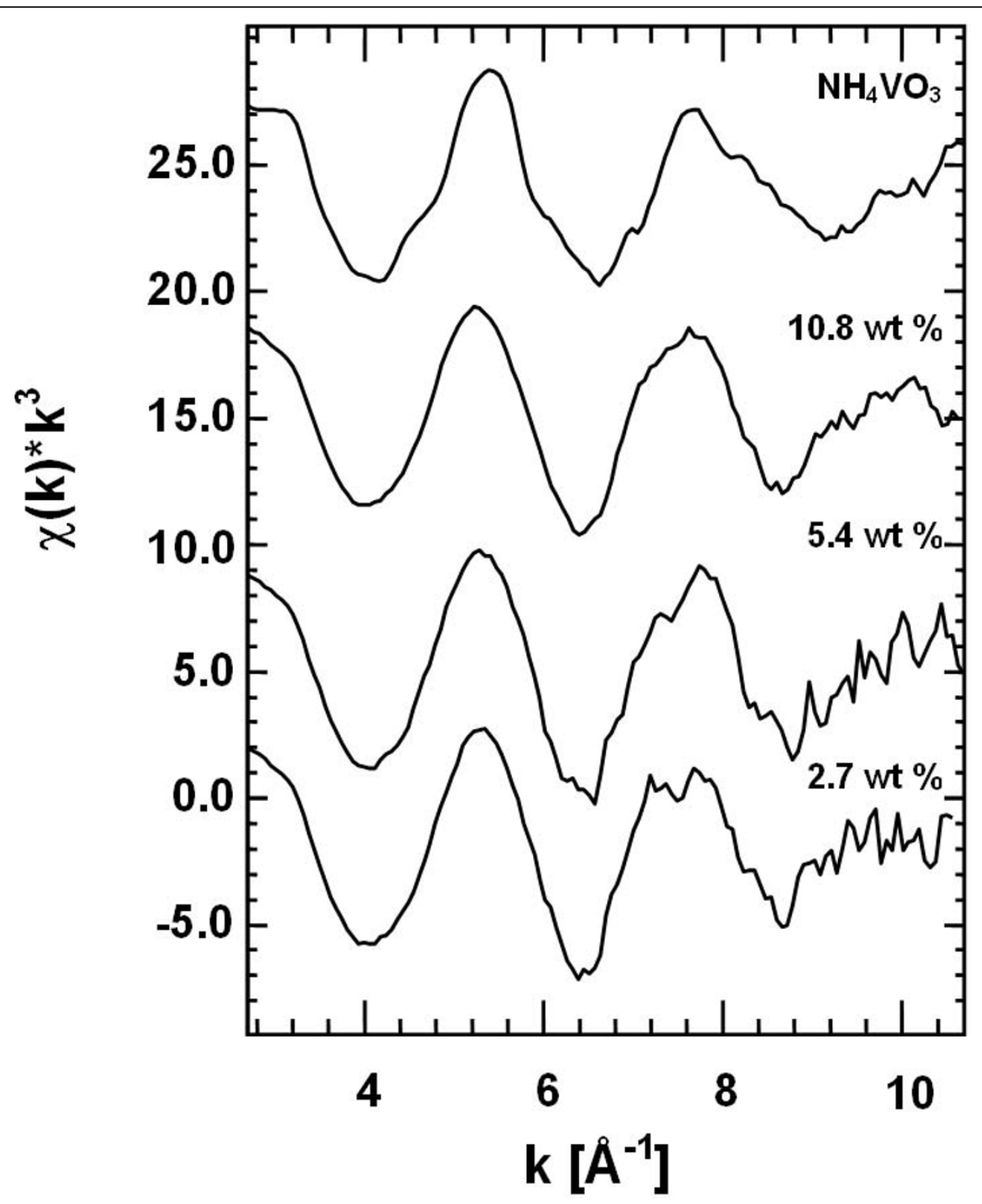

Figure $1 \mathrm{~V} \mathrm{~K}$ edge $\chi(k)$ of dehydrated $\mathrm{V}_{\mathrm{x}} \mathrm{O}_{\mathrm{y}} / \mathrm{SBA}-15$ with different vanadium loadings $(2.7 \mathrm{wt} \%, 5.4 \mathrm{wt} \%$, and 10.8 wt $\%)$ and reference $\mathrm{NH}_{4} \mathrm{VO}_{3}$. 


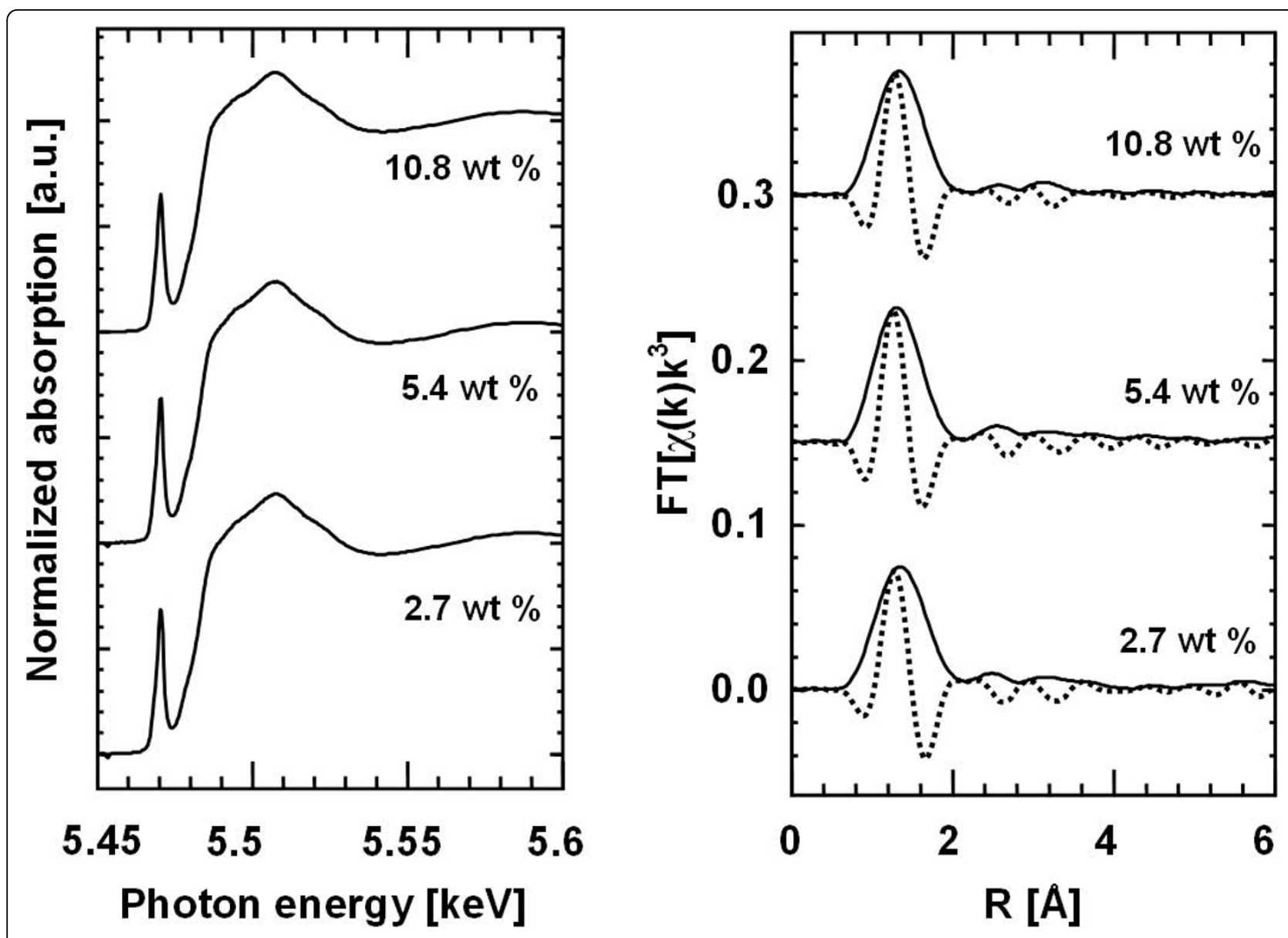

Figure $2 \mathrm{~V} K$ edge XANES spectra (a) and $\mathrm{FT}\left(\chi(k) * k^{3}\right)$ (b) of dehydrated $\mathrm{V}_{\mathrm{x}} \mathrm{O}_{\mathrm{y}} / \mathrm{SBA}-15$ samples with different vanadium loadings (2.7 wt $\%, 5.4$ wt $\%$, and 10.8 wt \%).

$\mathrm{V}_{\mathrm{x}} \mathrm{O}_{\mathrm{y}} / \mathrm{SBA}-15$. In the $\mathrm{FT}\left(\chi(\mathrm{k})^{*} \mathrm{k}^{3}\right)$ of $\mathrm{Na}_{3} \mathrm{VO}_{4}$ and $\mathrm{Mg}_{3} \mathrm{~V}_{2} \mathrm{O}_{8}$ the first $\mathrm{V}-\mathrm{O}$ peak is significantly higher than in the $\mathrm{FT}\left(\chi(\mathrm{k}) * \mathrm{k}^{3}\right)$ of dehydrated $\mathrm{V}_{\mathrm{x}} \mathrm{O}_{\mathrm{y}} / \mathrm{SBA}-15$. In contrast to the $\mathrm{FT}\left(\chi(\mathrm{k})^{*} \mathrm{k}^{3}\right)$ of $\mathrm{Mg}_{3} \mathrm{~V}_{2} \mathrm{O}_{8}$ which exhibits a significant amplitude at distances above $2 \AA$, the $\mathrm{FT}(\chi$ (k)" $\mathrm{k}^{3}$ ) of $\mathrm{Na}_{3} \mathrm{VO}_{4}, \mathrm{NH}_{4} \mathrm{VO}_{3}, \mathrm{Mg}_{2} \mathrm{~V}_{2} \mathrm{O}_{7}$, and dehydrated $\mathrm{V}_{\mathrm{x}} \mathrm{O}_{\mathrm{y}} / \mathrm{SBA}-15$ show little amplitude at higher distances. Moreover, looking at the differences between the $\mathrm{FT}(\chi$ $(\mathrm{k})^{*} \mathrm{k}^{3}$ ) of $\mathrm{Na}_{3} \mathrm{VO}_{4}, \mathrm{NH}_{4} \mathrm{VO}_{3}$, and $\mathrm{Mg}_{2} \mathrm{~V}_{2} \mathrm{O}_{7}$, the latter appears to yield the best agreement with that of dehydrated $\mathrm{V}_{\mathrm{x}} \mathrm{O}_{\mathrm{y}} / \mathrm{SBA}-15$. In all reference the low amplitude of the $\mathrm{FT}\left(\chi(\mathrm{k}) * \mathrm{k}^{3}\right)$ at $\mathrm{R}>2 \AA$ is characteristic of the local structure around the $\mathrm{V}$ centers. It is not caused by an increased amount of disorder. In total, based on comparing the XANES and $\mathrm{FT}\left(\chi(\mathrm{k}){ }^{*} \mathrm{k}^{3}\right)$ of dehydrated $\mathrm{V}_{\mathrm{x}} \mathrm{O}_{\mathrm{y}} / \mathrm{SBA}-15$ to those of potential references, $\mathrm{NH}_{4} \mathrm{VO}_{3}$ and $\mathrm{Mg}_{2} \mathrm{~V}_{2} \mathrm{O}_{7}$ have been identified as suitable references to serve as model systems for a more detailed structural analysis.

Before we discuss the details of analyzing the XAFS data of dehydrated $\mathrm{V}_{\mathrm{x}} \mathrm{O}_{\mathrm{y}} / \mathrm{SBA}-15$, a suitable analysis procedure for the higher $\mathrm{V}-\mathrm{V}$ contributions in the XAFS spectra of references $\mathrm{NH}_{4} \mathrm{VO}_{3}$ and $\mathrm{Mg}_{2} \mathrm{~V}_{2} \mathrm{O}_{7}$ was sought. As an example and to reduce the number of tables here, the application of confidence limits and $F$ parameter to distinguish analysis fitting procedures is described for two refinements of a suitable model structure to the experimental $\operatorname{FT}\left(\chi(\mathrm{k})^{*} \mathrm{k}^{3}\right)$ of dehydrated $\mathrm{V}_{\mathrm{x}} \mathrm{O}_{\mathrm{y}} / \mathrm{SBA}-15$. The model structure consisted of a tetrahedral coordination of the $\mathrm{V}$ center by four oxygen atoms at $\sim 1.7 \AA\left(\mathrm{NH}_{4} \mathrm{VO}_{3}\right)$, two vanadium atoms at distances at $\sim 3.4 \AA\left(\mathrm{NH}_{4} \mathrm{VO}_{3}\right)$ and $3.6 \AA\left(\mathrm{Mg}_{2} \mathrm{~V}_{2} \mathrm{O}_{7}\right)$, one oxygen atom at $\sim 2.9 \AA\left(\mathrm{Mg}_{2} \mathrm{~V}_{2} \mathrm{O}_{7}\right)$, and one $\mathrm{Si}$ atom at $\sim 2.8 \AA$ (Table 2). Experimental FT $\left(\chi(\mathrm{k})^{*} \mathrm{k}^{3}\right)$ of $\mathrm{Mg}_{2} \mathrm{~V}_{2} \mathrm{O}_{7}$ and $\mathrm{NH}_{4} \mathrm{VO}_{3}$ and the corresponding XAFS refinements are shown in Figure 4. Deviations between the theoretical and experimental spectrum of $\mathrm{Mg}_{2} \mathrm{~V}_{2} \mathrm{O}_{7}$ in the range from 2 - $4 \AA$ are caused by the number of $\mathrm{Mg}$ neighbors and nearly linear multiple-scattering paths in $\mathrm{Mg}_{2} \mathrm{~V}_{2} \mathrm{O}_{7}$ that contribute in this range. These are not sufficiently accounted for by the simplified refinement procedure. The results of the XAFS refinement for dehydrated 


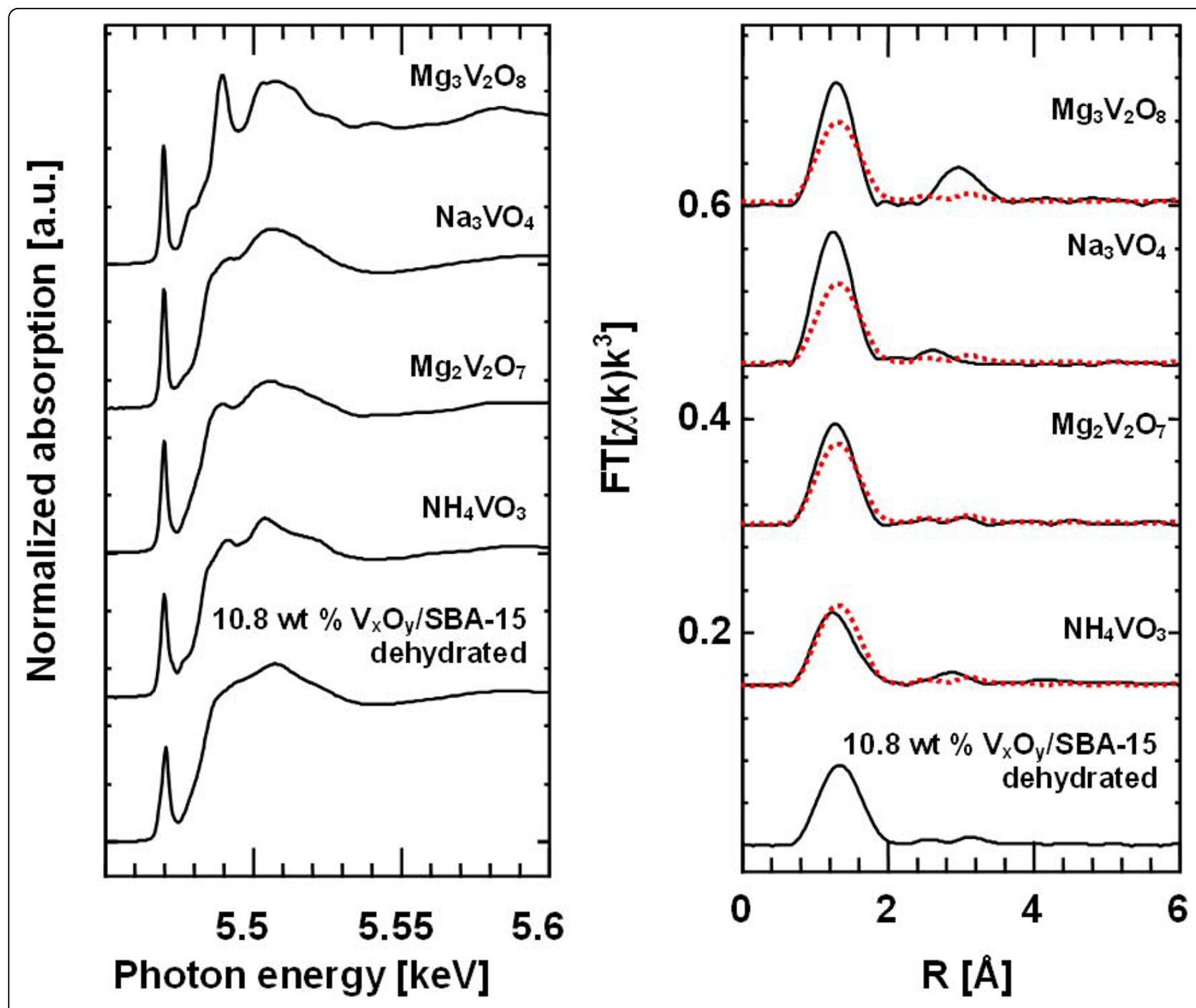

Figure $3 \mathrm{~V} K$ edge XANES spectra (a) and $\mathrm{FT}\left(\chi(k){ }^{*} \mathrm{k}^{3}\right)$ (b) of dehydrated $\mathrm{V}_{\mathrm{x}} \mathrm{O}_{\mathrm{y}} / \mathrm{SBA}-15$ (10.8 wt \%) (dashed on right side) compared to those of various references (i.e. $\mathrm{NH}_{4} \mathrm{VO}_{3}, \mathrm{Mg}_{2} \mathrm{~V}_{2} \mathrm{O}_{7}, \mathrm{Na}_{3} \mathrm{VO}_{4}$, and $\mathrm{Mg}_{3} \mathrm{~V}_{2} \mathrm{O}_{8}$ ).

$\mathrm{V}_{\mathrm{x}} \mathrm{O}_{\mathrm{y}} / \mathrm{SBA}-15, \mathrm{NH}_{4} \mathrm{VO}_{3}$, and $\mathrm{Mg}_{2} \mathrm{~V}_{2} \mathrm{O}_{7}$ are summarized in Table 2. Apparently, the distorted $\mathrm{VO}_{4}$ tetraeder in $\mathrm{NH}_{4} \mathrm{VO}_{3}$ required two different $\mathrm{V}-\mathrm{O}$ distances to be included in the refinement, while $\mathrm{Mg}_{2} \mathrm{~V}_{2} \mathrm{O}_{7}$ and dehydrated $\mathrm{V}_{\mathrm{x}} \mathrm{O}_{\mathrm{y}} / \mathrm{SBA}-15$ exhibited a similar single $\mathrm{V}-\mathrm{O}$ distance. It seems that the distortion in the $\mathrm{VO}_{4}$ units of crystalline reference $\mathrm{Mg}_{2} \mathrm{~V}_{2} \mathrm{O}_{7}$ could not be resolved by the XAFS analysis procedure employed. Accordingly, a lower $\sigma^{2}$ was obtained $\left(0.0012 \AA^{2}\right)$ for $\mathrm{NH}_{4} \mathrm{VO}_{3}$ compared to those of dehydrated $\mathrm{V}_{\mathrm{x}} \mathrm{O}_{\mathrm{y}} / \mathrm{SBA}-15$ and $\mathrm{Mg}_{2} \mathrm{~V}_{2} \mathrm{O}_{7}\left(0.0075 \AA^{2}\right.$ and $0.0059 \AA^{2}$, respectively). Contrarily, a single $\mathrm{V}-\mathrm{V}$ distance at $3.47 \AA(\mathrm{CN}=2)$ sufficed for $\mathrm{NH}_{4} \mathrm{VO}_{3}$ (consisting of chains of $\mathrm{VO}_{4}$ units), while two $\mathrm{V}-\mathrm{V}$ distances had to be included for $\mathrm{Mg}_{2} \mathrm{~V}_{2} \mathrm{O}_{7}$ (consisting of adjacent $\mathrm{V}_{2} \mathrm{O}_{7}$ units) and dehydrated $\mathrm{V}_{\mathrm{x}} \mathrm{O}_{\mathrm{y}} / \mathrm{SBA}-15$. In all three cases, a similar $\sigma^{2}$ parameter for the $\mathrm{V}-\mathrm{V}$ contributions of about $0.014 \AA^{2}$ was obtained.

The corresponding confidence limits and significance parameters $\mathrm{F}$ are given in Table 3 . In fitting procedure \#1 two V-O distances in the first V-O shell were allowed to vary independently (both with a $\mathrm{CN}$ of 2 and the same $\sigma^{2}$ ). Moreover, $\mathrm{E}_{0}$ was also allowed to vary in fitting procedure \#1. Because of $\mathrm{N}_{\text {ind }}=18$ and $\mathrm{N}_{\text {free }}=$ 11 refinement procedure \#1 would be taken as reliable according to the Nyquist criteria. However, confidence limits of the first $\mathrm{V}-\mathrm{O}$ distance of $\pm 0.1 \AA$ and an $\mathrm{F}$ parameter of 0.7 for both distance and $\sigma^{2}$ were obtained with procedure \#1. Moreover, $\mathrm{E}_{0}$ exhibited a confidence limit of \pm 9.2 and $F=0.9$. Apparently, fitting procedure \#1 already exceeds the number of meaningful parameters and yield ambiguous structural parameters. On 
Table 2 EXAFS refinement results obtained for experimental $\mathrm{FT}\left(\chi(k) * k^{3}\right)$ of dehydrated $\mathrm{V}_{\mathrm{x}} \mathrm{O}_{\mathrm{y}} / \mathrm{SBA}-15$, $\mathrm{NH}_{4} \mathrm{VO}_{3}$, and $\mathrm{Mg}_{2} \mathrm{~V}_{2} \mathrm{O}_{7}$.

\begin{tabular}{|c|c|c|c|c|c|c|c|c|}
\hline \multirow[b]{2}{*}{ Type } & \multicolumn{2}{|c|}{ Model } & \multicolumn{2}{|c|}{$V_{x} O_{y}-S B A-15$} & \multicolumn{2}{|c|}{$\mathrm{Mg}_{2} \mathrm{~V}_{2} \mathrm{O}_{7}$} & \multicolumn{2}{|l|}{$\mathrm{NH}_{4} \mathrm{VO}_{3}$} \\
\hline & $\mathbf{N}$ & $\mathrm{R}[\AA]$ & & $\left.{ }^{2}\right]$ & & {$\left[\AA^{2}\right]$} & & $\sigma[A$ \\
\hline $\mathrm{O}$ & 1 & 1.63 & 1.78 & 0.0075 & 1.74 & 0.0059 & 1.68 & 0.0012 \\
\hline$-\mathrm{O}$ & 1 & 1.70 & $1.78_{C}$ & $0.0075_{c}$ & $1.74_{C}$ & $0.0059_{C}$ & $1.68_{C}$ & $0.0012_{C}$ \\
\hline$-\mathrm{O}$ & 2 & 1.76 & $1.78_{C}$ & $0.0075_{c}$ & $1.74_{C}$ & $0.0059_{C}$ & 1.84 & $0.0012_{c}$ \\
\hline$-\mathrm{O}$ & 1 & 2.87 & 2.89 & 0.0017 & 2.77 & 0.0165 & - & - \\
\hline I-V & 1 & 3.36 & 3.30 & 0.0135 & 3.28 & 0.0134 & 3.47 & 0.0147 \\
\hline$-V$ & 1 & 3.62 & 3.62 & $0.0135 c$ & 3.56 & $0.0134_{C}$ & $3.47 \mathrm{C}$ & $0.0147_{C}$ \\
\hline /-Si & 1 & 2.80 & 2.54 & 0.0121 & - & - & - & - \\
\hline
\end{tabular}

Type and number $(\mathrm{N})$ of atoms at distance $\mathrm{R}$ from the absorbing $\mathrm{V}$ atom in a model system assuming an ordered arrangement of $\mathrm{V}_{2} \mathrm{O}_{7}$ units (Figure 7) compared to experimental distances and XAFS disorder parameters $\left(\sigma^{2}\right)$. Parameters were obtained from the refinement of this model structure to the experimental $\mathrm{V} \mathrm{K}$ edge XAFS FT $\left(\alpha(\mathrm{k}){ }^{*} \mathrm{~K}^{3}\right)$ of dehydrated $\mathrm{V}_{\mathrm{x}} \mathrm{O}_{\mathrm{y}} / \mathrm{SBA}-15$ (10.8 wt \%), $\mathrm{Mg}_{2} \mathrm{~V}_{2} \mathrm{O}_{7}$, and $\mathrm{NH}_{4} \mathrm{VO}_{3}$ (k range from 2.7-11.0 $\AA^{-1}, \mathrm{R}$ range 0.8-4.0 $\AA, \mathrm{N}_{\text {ind }}=$ $18, E_{0}=0 \mathrm{eV}$ in all cases, fit residual 3.6 (dehydrated $\left.\mathrm{V}_{\mathrm{x}} \mathrm{O}_{\mathrm{y}} / \mathrm{SBA}-15\right)\left(\mathrm{N}_{\text {free }}=9\right.$ ), $\left.11.2\left(\mathrm{Mg}_{2} \mathrm{~V}_{2} \mathrm{O}_{7}\right)\left(\mathrm{N}_{\text {free }}=7\right), 8.9\left(\mathrm{NH}_{4} \mathrm{VO}_{3}\right)\left(\mathrm{N}_{\text {free }}=5\right)\right)$ (Subscript $\mathrm{C}$ indicates parameters that were correlated in the refinement). Confidence limits and significance of fitting parameters are given in Table 3.

the one hand, the reduced amplitude of the $\mathrm{FT}\left(\chi(\mathrm{k})^{*} \mathrm{k}^{3}\right)$ of dehydrated $\mathrm{V}_{\mathrm{x}} \mathrm{O}_{\mathrm{y}} / \mathrm{SBA}-15$ compared to that of references consisting of undistorted $\mathrm{VO}_{4}$ units (Figure 3) suggested the presence of more than one $\mathrm{V}-\mathrm{O}$ distance, including a short "vanadyl" $\mathrm{V}=\mathrm{O}$ distance. On the other hand, however, the resolution in the experimental $\mathrm{FT}\left(\chi(\mathrm{k}) * \mathrm{k}^{3}\right)$ and the available degree of freedom did not permit refining more than one $\mathrm{V}-\mathrm{O}$ distance in the procedure used. Therefore, the fitting procedure was modified. In the following, $E_{0}$ was kept invariant in the refinement and only one V-O distance at $\sim 1.75 \AA$ was used. In contrast to procedure \#1, procedure \#2 yielded reasonable confidence limits and acceptable $\mathrm{F}$ parameters.

The $\sigma^{2}$ parameter of the $\mathrm{V}-\mathrm{O}$ contribution at $2.9 \AA$ exhibited a rather high confidence limit and $\mathrm{F}=0.7$. Apparently, both V-O and V-Si neighbors in the distance range from $2.5 \AA$ to $2.9 \AA$ are required for a good refinement of the model structure to the experimental data. This is indicated by the confidence limits and $F$ parameters calculated for the corresponding distances (Table 3). Nevertheless, the high $\sigma^{2}$ obtained for the VSi contribution and the rather low $\sigma^{2}$ obtained for the $\mathrm{V}-\mathrm{O}$ at $2.9 \AA$ indicate a certain ambiguity of the corresponding fitting results. The reason may be a considerable static disorder and, thus, a broadened V-Si distance distribution. Hence, calculating and evaluating confidence limits and $\mathrm{F}$ tests permitted to arrive at a meaningful and reliable fitting procedure. In that, the approach employed appears to be superior to only calculating the Nyquist criteria. In total, procedure \#2 worked very well for XAFS data analysis of dehydrated $\mathrm{V}_{\mathrm{x}} \mathrm{O}_{\mathrm{y}} / \mathrm{SBA}-15$ and $\mathrm{Mg}_{2} \mathrm{~V}_{2} \mathrm{O}_{7}$. In contrast, the local structure around $\mathrm{V}$ centers in $\mathrm{NH}_{4} \mathrm{VO}_{3}$ was best described by assuming two different $\mathrm{V}-\mathrm{O}$ distances in the first coordination shell and only one $\mathrm{V}-\mathrm{V}$ distance at $3.47 \AA(\mathrm{CN}=2)($ Table 2). A V-O distance at $2.8 \AA$ was found to be insignificant.

\section{Local structure of dehydrated $\mathrm{V}_{\mathrm{x}} \mathrm{O}_{\mathrm{y}} / \mathrm{SBA}-15$ - XAFS \\ refinement of " $\mathrm{VO}_{4}$ " based model structures}

After having identified two suitable references as model structures for XAFS refinements to the experimental FT $\left(\chi(k) * k^{3}\right)$ of dehydrated $\mathrm{V}_{\mathrm{x}} \mathrm{O}_{\mathrm{y}} / \mathrm{SBA}-15$ (Figure $3(\mathrm{~b})$ ), the XAFS analysis approach chosen shall be described in more detail. In addition to using confidence limits and $\mathrm{F}$ tests as introduced above, the suitable XAFS fitting procedure was developed stepwise as outlined in the following.

First, we started with an often repeated assumption from the literature. DR-UV-Vis or Raman measurements revealed that dehydration of $\mathrm{V}_{\mathrm{x}} \mathrm{O}_{\mathrm{y}} / \mathrm{SBA}-15$ resulted in a characteristic change from a distorted square pyramidal to a distorted tetrahedral coordination $[10,13,16]$. The local structure of vanadium oxide species supported on $\mathrm{SiO}_{2}$ was assumed to correspond to isolated $\mathrm{VO}_{4}$ units. Hence, in a first tetrahedron approach the theoretical XAFS function of a $\mathrm{VO}_{4}$ tetrahedron consisting of two slightly different $\mathrm{V}-\mathrm{O}$ distances was refined to the $\mathrm{FT}(\chi$ $(\mathrm{k})^{*} \mathrm{k}^{3}$ ) of dehydrated $\mathrm{V}_{\mathrm{x}} \mathrm{O}_{\mathrm{y}} / \mathrm{SBA}-15$ (Figure 5, top) together with the Fourier transformed $\chi(k) * k^{3}$ of the individual scattering paths). Because of the similar height of the pre-edge peak in the XANES (Figure 3(a)) and the first $\mathrm{V}-\mathrm{O}$ peak in the $\mathrm{FT}\left(\chi(\mathrm{k})^{*} \mathrm{k}^{3}\right)$, phases and amplitudes employed in the refinement were calculated using the model structure of $\mathrm{NH}_{4} \mathrm{VO}_{3}$ (ICSD 1487 [26]) and $\mathrm{Mg}_{2} \mathrm{~V}_{2} \mathrm{O}_{7}$ (ISCD 2321 [27]). Figure 5, top shows a good agreement between theoretical and experimental $\mathrm{FT}\left(\chi(\mathrm{k})^{*} \mathrm{k}^{3}\right)$ of dehydrated $\mathrm{V}_{\mathrm{x}} \mathrm{O}_{\mathrm{y}} / \mathrm{SBA}-15$ for the first VO peak below $2 \AA$. Naturally, the amplitude between 2 $\AA$ and $4 \AA$ in the $\mathrm{FT}\left(\chi(\mathrm{k})^{*} \mathrm{k}^{3}\right)$ could not be accounted for. Hence, a structural model assuming only isolated $\mathrm{VO}_{4}$ species cannot adequately describe the local structure around the $\mathrm{V}$ centers in dehydrated $\mathrm{V}_{\mathrm{x}} \mathrm{O}_{\mathrm{y}} / \mathrm{SBA}-15$.

Therefore, we assumed that higher coordination shells around the vanadium centers significantly contribute to the $\mathrm{FT}\left(\chi(\mathrm{k}) * \mathrm{k}^{3}\right)$ of dehydrated $\mathrm{V}_{\mathrm{x}} \mathrm{O}_{\mathrm{y}} / \mathrm{SBA}-15$. These shells have to be included in the refinement. A seemingly expected contribution may arise from silicon backscatterers in the $\mathrm{SiO}_{2}$ support at distances of less than $3.0 \AA$. This has been previously proposed by Keller et al. [20]. Thus, in extension of the tetrahedron approach a silicon atom at a V-Si distance of $2.8 \AA$ was included in the theoretical model. In the corresponding " $\mathrm{O}_{3} \mathrm{~V}-\mathrm{O}-\mathrm{Si}$ " unit a Si-O distance of $1.62 \AA$ is assumed (inset in Figure 5, bottom)), as it is found in various silicates. The result of the XAFS refinement of the " $\mathrm{O}_{3} \mathrm{~V}$ - 

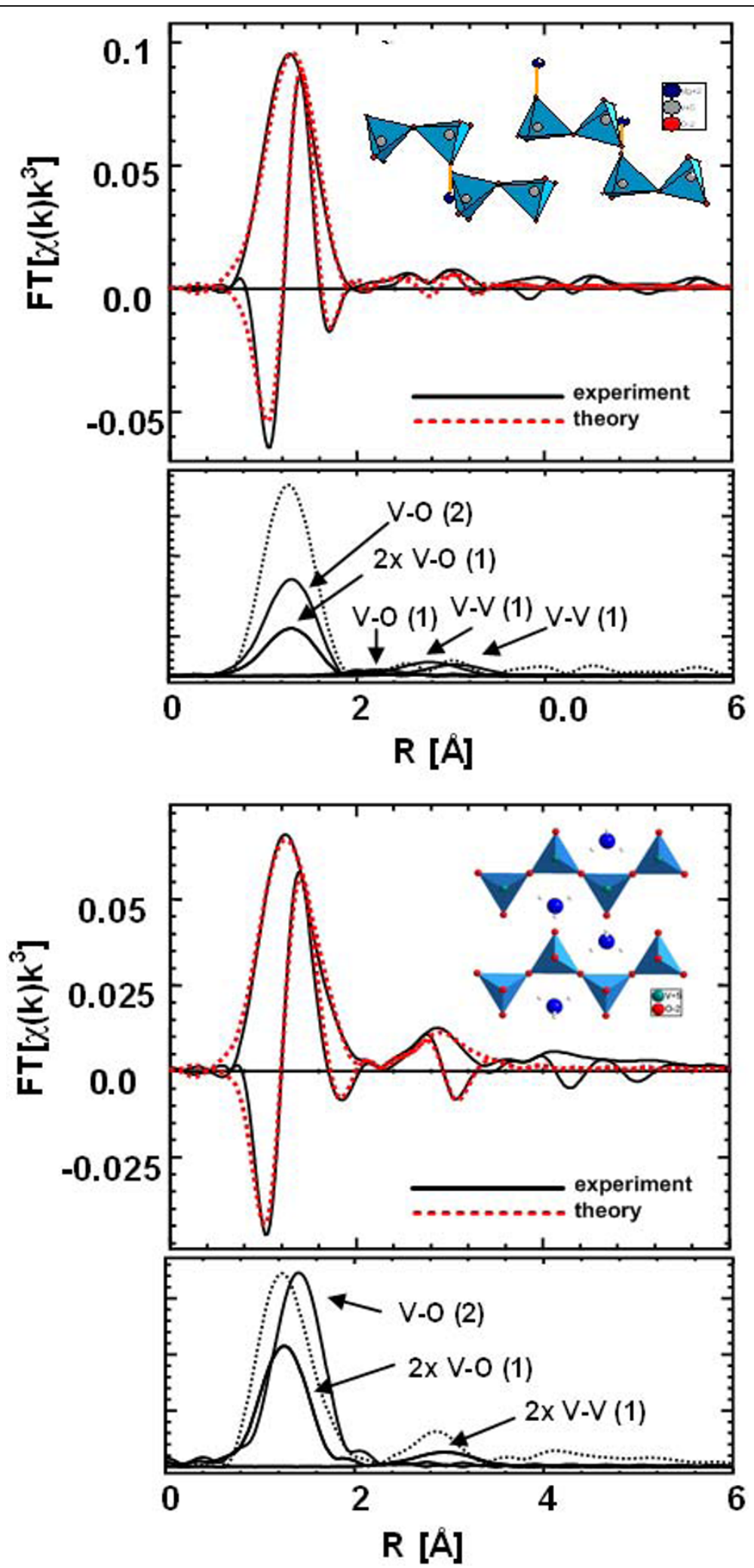

Figure 4 Experimental (solid) $\mathrm{V} \mathrm{K}$ edge $\mathrm{FT}\left(\chi(\mathbf{k})^{*} \mathrm{k}^{3}\right)$ of $\mathrm{NH}_{4} \mathrm{VO}_{3}, \mathrm{Mg}_{2} \mathrm{~V}_{2} \mathrm{O}_{7}$ reference together with a theoretical XAFS function (fitting results are given in Table 2). Also shown are the Fourier transformed $\chi(k)^{*} k^{3}$ of the individual scattering paths together with corresponding coordination number in brackets. brackets. 
Table 3 Evaluation of EXAFS refinement of dehydrated $\mathrm{V}_{\mathrm{x}} \mathrm{O}_{\mathrm{y}} / \mathrm{SBA}-15$.

\begin{tabular}{|c|c|c|c|c|c|c|c|}
\hline \multirow{2}{*}{$\begin{array}{l}\text { Type } \\
R[\AA] \\
\sigma^{2}\left[\AA^{2}\right]\end{array}$} & \multirow[b]{2}{*}{$\mathbf{N}$} & \multicolumn{3}{|c|}{ Procedure \#1 } & \multicolumn{3}{|c|}{ Procedure \#2 } \\
\hline & & $\mathbf{Z}$ & $\pm z$ & $\mathbf{F}$ & $\mathbf{Z}$ & $\pm z$ & $\mathbf{F}$ \\
\hline $\mathrm{R}(\mathrm{V}-\mathrm{O})$ & $4(2)$ & 1.81 & 0.11 & 0.7 & 1.78 & 0.005 & 0 \\
\hline$\sigma^{2}(\mathrm{~V}-\mathrm{O})$ & 4 & 0.0066 & 0.0047 & 0.7 & 0.0075 & 0.0004 & 0 \\
\hline $\mathrm{R}(\mathrm{V}-\mathrm{O})$ & $-(2)$ & 1.75 & 0.04 & 0.4 & - & - & \\
\hline $\mathrm{R}(\mathrm{V}-\mathrm{O})$ & 1 & 2.89 & 0.01 & 0.5 & 2.90 & 0.011 & 0 \\
\hline$\sigma^{2}(\mathrm{~V}-\mathrm{O})$ & 1 & 0.0014 & 0.0017 & 0.9 & 0.0017 & 0.0018 & 0.7 \\
\hline $\mathrm{R}(\mathrm{V}-\mathrm{V})$ & 1 & 3.29 & 0.017 & 0 & 3.29 & 0.016 & 0 \\
\hline$\sigma^{2}(V-V)$ & 2 & 0.0135 & 0.0203 & 0.7 & 0.0135 & 0.00035 & 0.3 \\
\hline$R(V-V)$ & 1 & 3.61 & 0.019 & 0 & 3.62 & 0.024 & 0 \\
\hline $\mathrm{R}(\mathrm{V}-\mathrm{Si})$ & 1 & 2.54 & 0.01 & 0 & 2.54 & 0.011 & 0 \\
\hline$\sigma^{2}(\mathrm{~V}-\mathrm{Si})$ & 1 & 0.0115 & 0.0011 & 0.3 & 0.0121 & 0.0011 & 0 \\
\hline $\mathrm{E}_{0}$ & - & -0.9 & -0.3 & 0.8 & - & - & - \\
\hline
\end{tabular}

$\mathrm{V} \mathrm{K}$ edge XAFS parameters ( $\mathrm{Z}$ for distances $\mathrm{R}$ and disorder parameter $\sigma^{2}$ ) obtained from two different procedures of fitting a model structure (i.e. "ordered $\mathrm{V}_{2} \mathrm{O}_{7}$ dimers" on $\mathrm{SiO}_{2}$ support) to the experimental XAFS FT $\left(\chi(k)^{*} k^{3}\right)$ of dehydrated $\mathrm{V}_{\mathrm{x}} \mathrm{O}_{\mathrm{y}} / \mathrm{SBA}-15$ (10.8 wt \%) (details of fit given in Table 2) together with confidence limits ( $\pm z$, referring to $95 \%$ of fit residual) and significance parameters $F$ (details given in text). Fit residual 3.1 for Procedure $\# 1$ and 3.6 for Procedure \#2.

O-Si" model to the $\mathrm{FT}\left(\chi(\mathrm{k}) * \mathrm{k}^{3}\right)$ of dehydrated $\mathrm{V}_{\mathrm{x}} \mathrm{O}_{\mathrm{y}} /$ SBA-15 is depicted in Figure 5, bottom). The additional Si backscatterer resulted in a better agreement between theoretical and experimental $\mathrm{FT}\left(\chi(\mathrm{k}) * \mathrm{k}^{3}\right)$ at distances of about 2.4 $\AA$ (not phase shift corrected). The resulting VSi distance amounted to $2.54 \AA$, comparable to the distance obtained by Keller et al. (2.61 $\AA$ [20]). However, it can be easily seen from Figure 5, bottom) that the amplitude in the $\mathrm{FT}\left(\chi(\mathrm{k})^{*} \mathrm{k}^{3}\right)$ of dehydrated $\mathrm{V}_{\mathrm{x}} \mathrm{O}_{\mathrm{y}} / \mathrm{SBA}$ 15 between 2.4 and $4.0 \AA$ is still not accounted for.

\section{Local structure of dehydrated $\mathrm{V}_{\mathrm{x}} \mathrm{O}_{\mathrm{y}} / \mathrm{SBA}-15$ - XAFS refinement of " $\mathrm{V}_{2} \mathrm{O}_{7}$ " based model structures}

Figure 5 shows that an "isolated $\mathrm{VO}_{4}$ " model did not properly describe the local structure between $2 \AA$ and 4 $\AA$ around vanadium centers in dehydrated $\mathrm{V}_{\mathrm{x}} \mathrm{O}_{\mathrm{y}} / \mathrm{SBA}$ 15 . Hence, we assumed that at least " $\mathrm{V}_{2} \mathrm{O}_{7}$ dimers" would be needed to achieve a good agreement between theoretical and experimental XAFS FT $\left(\chi(k)^{*} k^{3}\right) . V_{2} \mathrm{O}_{7}$ units are present in the structures of the references $\mathrm{NH}_{4} \mathrm{VO}_{3}$ and $\mathrm{Mg}_{2} \mathrm{~V}_{2} \mathrm{O}_{7}$ whose spectra resembled best the XANES and EXAFS spectra of dehydrated $\mathrm{V}_{\mathrm{x}} \mathrm{O}_{\mathrm{y}} /$ SBA-15 (Figure 3). Therefore, a $\mathrm{V}-\mathrm{V}$ scattering path at 3.4 $\AA$ was included in the model used in the XAFS refinement. This distance corresponds to the shortest V$\mathrm{V}$ distance between two corner-sharing $\mathrm{VO}_{4}$ tetrahedrons in " $\mathrm{V}_{2} \mathrm{O}_{7}$ dimers" of $\mathrm{NH}_{4} \mathrm{VO}_{3}$ and $\mathrm{Mg}_{2} \mathrm{~V}_{2} \mathrm{O}_{7}$. The result of the corresponding XAFS refinement is shown in. Apparently, a structural model based on isolated $\mathrm{V}_{2} \mathrm{O}_{7}$ dimers was equally unsuited to describe the local structure around $\mathrm{V}$ centers in dehydrated $\mathrm{V}_{\mathrm{x}} \mathrm{O}_{\mathrm{y}} /$ SBA- 15 . The agreement between theoretical and experimental $\operatorname{FT}\left(\chi(\mathrm{k})^{*} \mathrm{k}^{3}\right)$ in the range from 2 to $4 \AA$ is still not sufficient (Figure 6). Also, adding a $\mathrm{V}-\mathrm{Si}$ distance to this "isolated $\mathrm{V}_{2} \mathrm{O}_{7}$ dimer model" only resulted in a minor improvement of the refinement.

Figure 5 and Figure 6 clearly show that neither an "isolated $\mathrm{VO}_{4}$ " model nor an "isolated $\mathrm{V}_{2} \mathrm{O}_{7}$ " model properly describe the local structure of the majority of $\mathrm{V}$ centers in dehydrated $\mathrm{V}_{\mathrm{x}} \mathrm{O}_{\mathrm{y}} / \mathrm{SBA}-15$. Hence, in the next step an ordered arrangement of neighboring $\mathrm{V}_{2} \mathrm{O}_{7}$ units was assumed. Because of their similar XANES and EXAFS spectra, we again referred to $\mathrm{NH}_{4} \mathrm{VO}_{3}$ and $\mathrm{Mg}_{2} \mathrm{~V}_{2} \mathrm{O}_{7}$ as references. $\mathrm{V}_{2} \mathrm{O}_{7}$ units form chains in $\mathrm{NH}_{4} \mathrm{VO}_{3}$ with one $\mathrm{V}-\mathrm{V}$ distance. Conversely, $\mathrm{V}_{2} \mathrm{O}_{7}$ units are neighboring but more separated in $\mathrm{Mg}_{2} \mathrm{~V}_{2} \mathrm{O}_{7}$ resulting in two distinct V-V distances (ICSD 2321 [27]). Accordingly, two additional scattering paths were added to the previous "isolated $\mathrm{V}_{2} \mathrm{O}_{7}$ " model. These two paths correspond to V-O (2.8 $\AA$ ) and V-V (3.6 $)$ ) distances between two neighboring $\mathrm{V}_{2} \mathrm{O}_{7}$ units in the structure of $\mathrm{Mg}_{2} \mathrm{~V}_{2} \mathrm{O}_{7}$. The result of the corresponding XAFS refinement to the $\mathrm{FT}\left(\chi(\mathrm{k})^{*} \mathrm{k}^{3}\right)$ of dehydrated $\mathrm{V}_{\mathrm{x}} \mathrm{O}_{\mathrm{y}} /$ SBA-15 is shown in Figure 7 together with the various $\mathrm{V}-\mathrm{O}$ and $\mathrm{V}-\mathrm{V}$ distances used. Apparently, assuming neighboring $\mathrm{V}_{2} \mathrm{O}_{7}$ units in an ordered arrangement supported on SBA-15 yielded a good agreement between theoretical and experimental $\mathrm{FT}\left(\chi(\mathrm{k}) * \mathrm{k}^{3}\right)$ of dehydrated $\mathrm{V}_{\mathrm{x}} \mathrm{O}_{\mathrm{y}} / \mathrm{SBA}$ 15 over the extended $\mathrm{R}$ range from $1 \AA$ to $4 \AA$. The structural and fitting parameters obtained from the XAFS refinement to the experimental FT $\left(\chi(k) * k^{3}\right)$ of dehydrated $\mathrm{V}_{\mathrm{x}} \mathrm{O}_{\mathrm{y}} / \mathrm{SBA}-15$ and $\mathrm{Mg}_{2} \mathrm{~V}_{2} \mathrm{O}_{7}$ are given in Table 2. The similar $\mathrm{V}-\mathrm{O}$ distances, $\mathrm{V}-\mathrm{V}$ distances, and $\sigma^{2}$ parameters of dehydrated $\mathrm{V}_{\mathrm{x}} \mathrm{O}_{\mathrm{y}} / \mathrm{SBA}-15$ and $\mathrm{Mg}_{2} \mathrm{~V}_{2} \mathrm{O}_{7}$ corroborate our choice of model system to describe the local structure around $\mathrm{V}$ centers dehydrated $\mathrm{V}_{\mathrm{x}} \mathrm{O}_{\mathrm{y}} /$ SBA-15.

\section{Schematic structural representation of dehydrated $\mathrm{V}_{\mathrm{x}} \mathrm{O}_{\mathrm{y}} /$ SBA-15}

A schematic structural representation of the ordered arrangement of $\mathrm{V}_{2} \mathrm{O}_{7}$ units in dehydrated $\mathrm{V}_{\mathrm{x}} \mathrm{O}_{\mathrm{y}} /$ SBA- 15 is depicted in Figure 8. In contrast to previous results on low loaded $\left(<1 \mathrm{~V} / \mathrm{nm}^{2}\right) \mathrm{V}_{\mathrm{x}} \mathrm{O}_{\mathrm{y}} / \mathrm{SiO}_{2}$ samples $[17,21]$ we conclude that isolated $\mathrm{VO}_{4}$ units are not the major vanadium oxide species present on the dehydrated $\mathrm{V}_{\mathrm{x}} \mathrm{O}_{\mathrm{y}} / \mathrm{SBA}-15$ samples studied here. From the different loadings studied, only the $2.7 \mathrm{wt} \% \mathrm{~V}_{\mathrm{x}} \mathrm{O}_{\mathrm{y}} / \mathrm{SBA}-15$ sample possessed a vanadium content of less than $1 \mathrm{~V} / \mathrm{nm}^{2}$. The three dehydrated $\mathrm{V}_{\mathrm{x}} \mathrm{O}_{\mathrm{y}} / \mathrm{SBA}-15$ samples exhibited only minor differences in their XANES spectra (Figure 2), $\mathrm{FT}\left(\chi(\mathrm{k})^{*} \mathrm{k}^{3}\right)$ (Figure 9), and XAFS fitting results (Table 4). Hence, independent of the $\mathrm{V}$ loading 

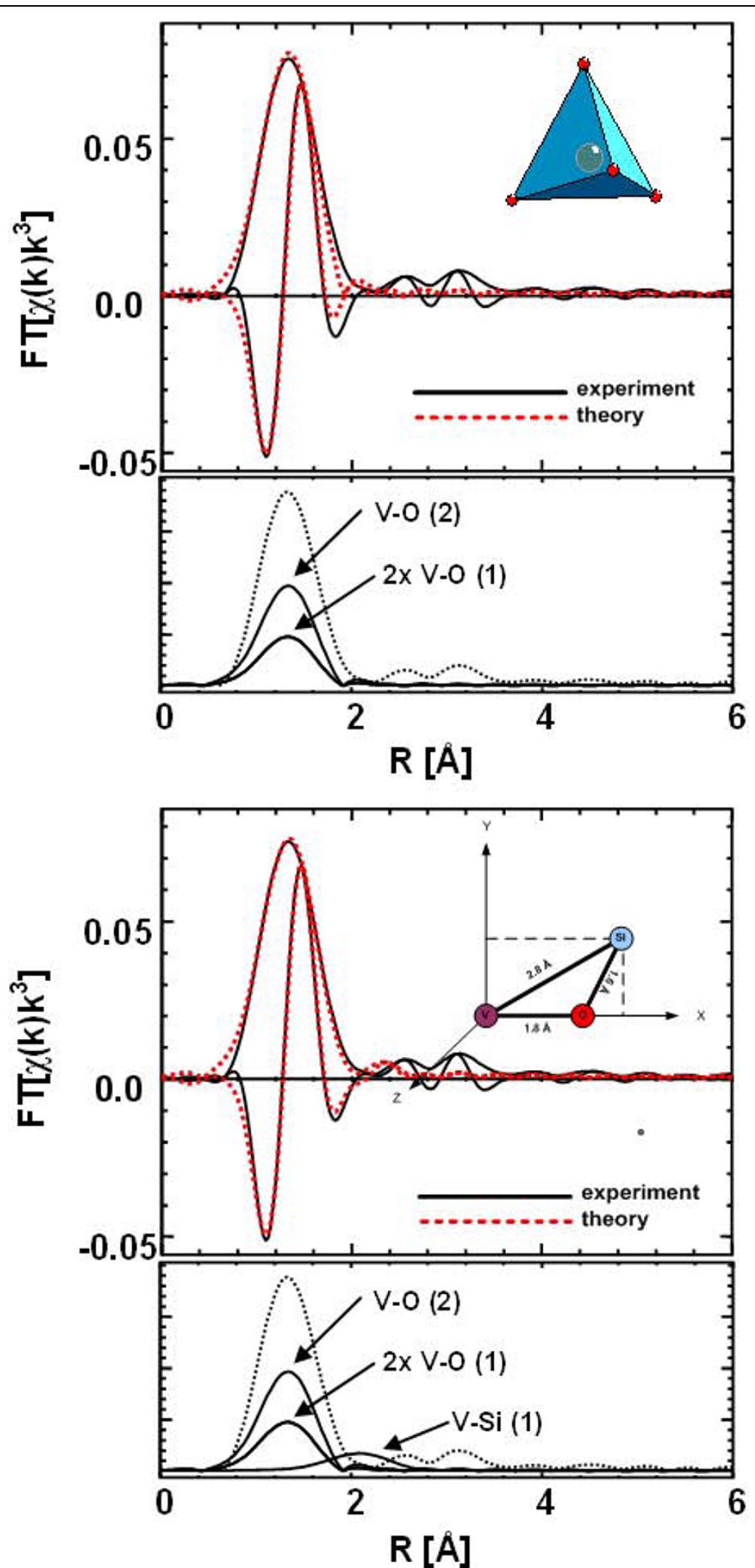

Figure 5 Experimental (solid) $V \mathrm{~K}$ edge $\mathrm{FT}\left(\chi(\mathbf{k})^{*} \mathrm{~K}^{3}\right)$ of dehydrated $\mathrm{V}_{\mathrm{x}} \mathrm{O}_{\mathrm{y}} / \mathrm{SBA}-15(10.8 \mathrm{wt} \%)$ together with theoretical XAFS functions (top: "isolated $\mathrm{VO}_{4}$ " model, bottom: addition of $\mathbf{V}$-Si path to "isolated $\mathrm{VO}_{4}$ " model). Insets show the $\mathrm{VO}_{4}$ tetrahedron (top) and a schematic representation of the $\mathrm{V}$-Si path employed (bottom). Also shown are the Fourier transformed $\chi(\mathrm{k})^{*} \mathrm{k}^{3}$ of the individual scattering paths together with corresponding coordination number in. 


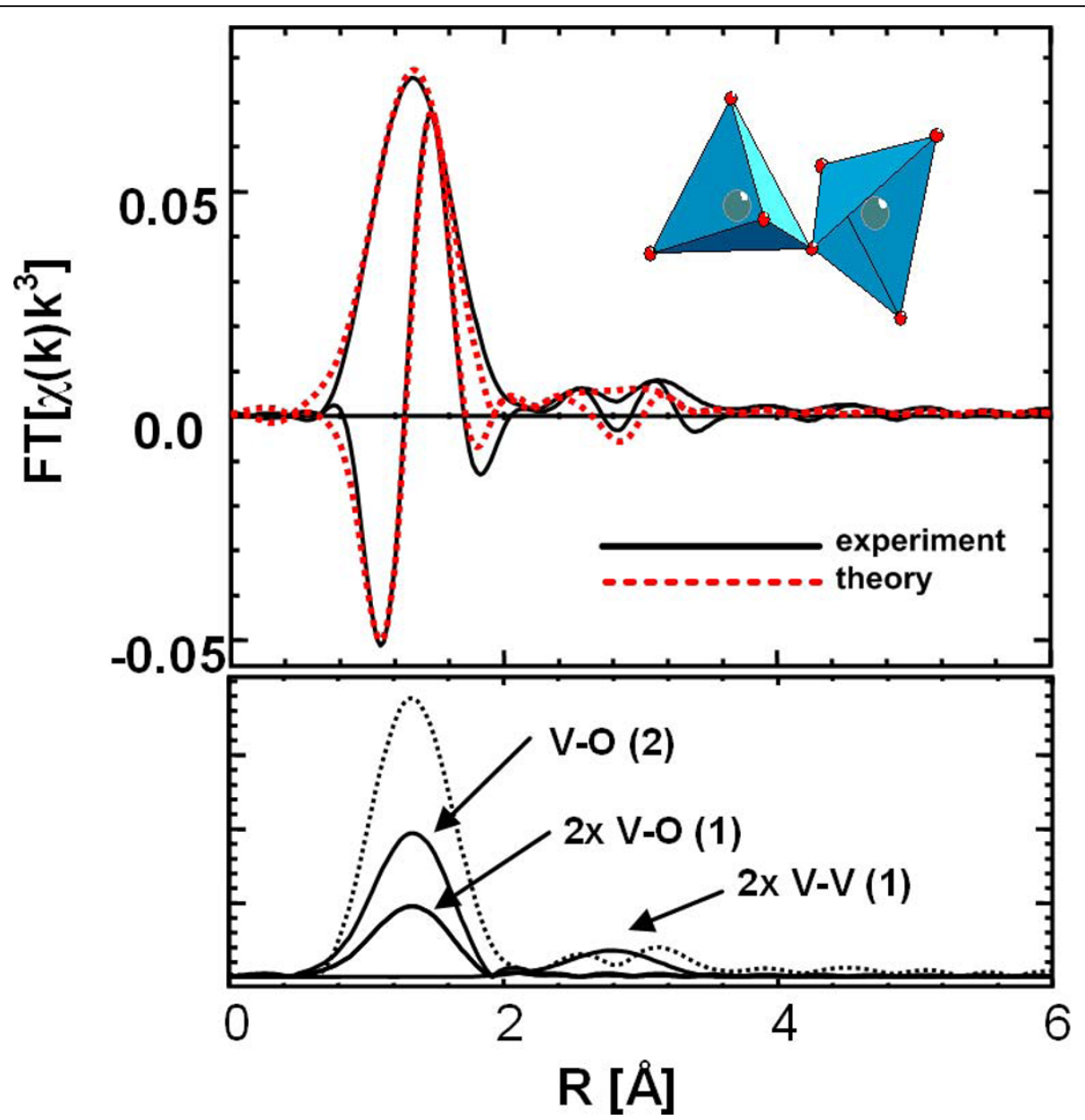

Figure 6 Experimental (solid) $\mathrm{V} \mathrm{K}$ edge $\mathrm{FT}\left(\chi(k) * k^{3}\right)$ of dehydrated $\mathrm{V}_{\mathrm{x}} \mathrm{O}_{\mathrm{y}} / \mathrm{SBA}-15$ (10.8 wt \%) together with a theoretical XAFS function (i.e. "isolated $\mathbf{V}_{\mathbf{2}} \mathrm{O}_{\mathbf{7}}$ " model). Inset shows the $\mathrm{V}_{2} \mathrm{O}_{7}$ dimer. Also shown are the Fourier transformed $\chi(\mathrm{k})^{*} \mathrm{k}^{3}$ of the individual scattering paths together with corresponding coordination number in brackets.

in the range $2.7-10.8 \mathrm{wt} \%$ the local structure of the majority of $\mathrm{V}$ centers in dehydrated $\mathrm{V}_{\mathrm{x}} \mathrm{O}_{\mathrm{y}} / \mathrm{SBA}-15$ is described best by an ordered arrangement of neighboring $\mathrm{V}_{2} \mathrm{O}_{7}$ units (Table 4, Figure 9). Decomposition of the decavanadate precursor during calcinations of the as-prepared materials will most likely result in the formation of dehydrated $\mathrm{V}_{\mathrm{x}} \mathrm{O}_{\mathrm{y}} / \mathrm{SBA}-15$. Any description of the formation mechanism of ordered $\mathrm{V}_{2} \mathrm{O}_{7}$ units on the surface of $\mathrm{SiO}_{2}$, however, is beyond the scope of this work. Exposure of the calcined material to ambient conditions apparently results in re-hydration and formation of the hydrated $\mathrm{V}_{\mathrm{x}} \mathrm{O}_{\mathrm{y}}$ species supported on SBA-15. This transformation already suggests a reversible hydration-re-hydration behavior of vanadium oxide species supported on SBA-15 which should be the subject of further studies.

The presence of non-monomeric $\mathrm{V}_{\mathrm{x}} \mathrm{O}_{\mathrm{y}}$ species in dehydrated $\mathrm{V}_{\mathrm{x}} \mathrm{O}_{\mathrm{y}} /$ SBA-15 samples was also recently concluded based on NEXAFS studies combined with theoretical calculations [28]. Eventually, structural evolution and catalytic activity of dehydrated $\mathrm{V}_{\mathrm{x}} \mathrm{O}_{\mathrm{y}} / \mathrm{SBA}-15$ were studied by combined in situ XAS-MS under selective propene oxidation reaction condition. Onset of catalytic activity was detected at about $573 \mathrm{~K}$. The in situ XAS data measured indicated, that the characteristic ordered arrangement of $\mathrm{V}_{2} \mathrm{O}_{7}$ dimers in the local structure of dehydrated $\mathrm{V}_{\mathrm{x}} \mathrm{O}_{\mathrm{y}} / \mathrm{SBA}-15$ persisted under catalytic reaction conditions. A more detailed analysis of structure activity correlations of $\mathrm{V}_{\mathrm{x}} \mathrm{O}_{\mathrm{y}} / \mathrm{SBA}-15$ under selective oxidation reaction conditions will be presented elsewhere.

Oxygen and silicon atoms of the $\mathrm{SiO}_{2}$ support are not depicted in the schematic representation depicted in Figure 8. In particular $\mathrm{Si}$ atoms in the topmost layer of $\mathrm{SiO}_{2}$ belong to the second coordination sphere of the $\mathrm{V}$ centers. Previous reports have indicated that V-Si distances may contribute to the experimental $\mathrm{FT}\left(\chi(\mathrm{k})^{*} \mathrm{k}^{3}\right)$ of dehydrated $\mathrm{V}_{\mathrm{x}} \mathrm{O}_{\mathrm{y}} / \mathrm{SBA}-15$ [19]. Therefore, a single 


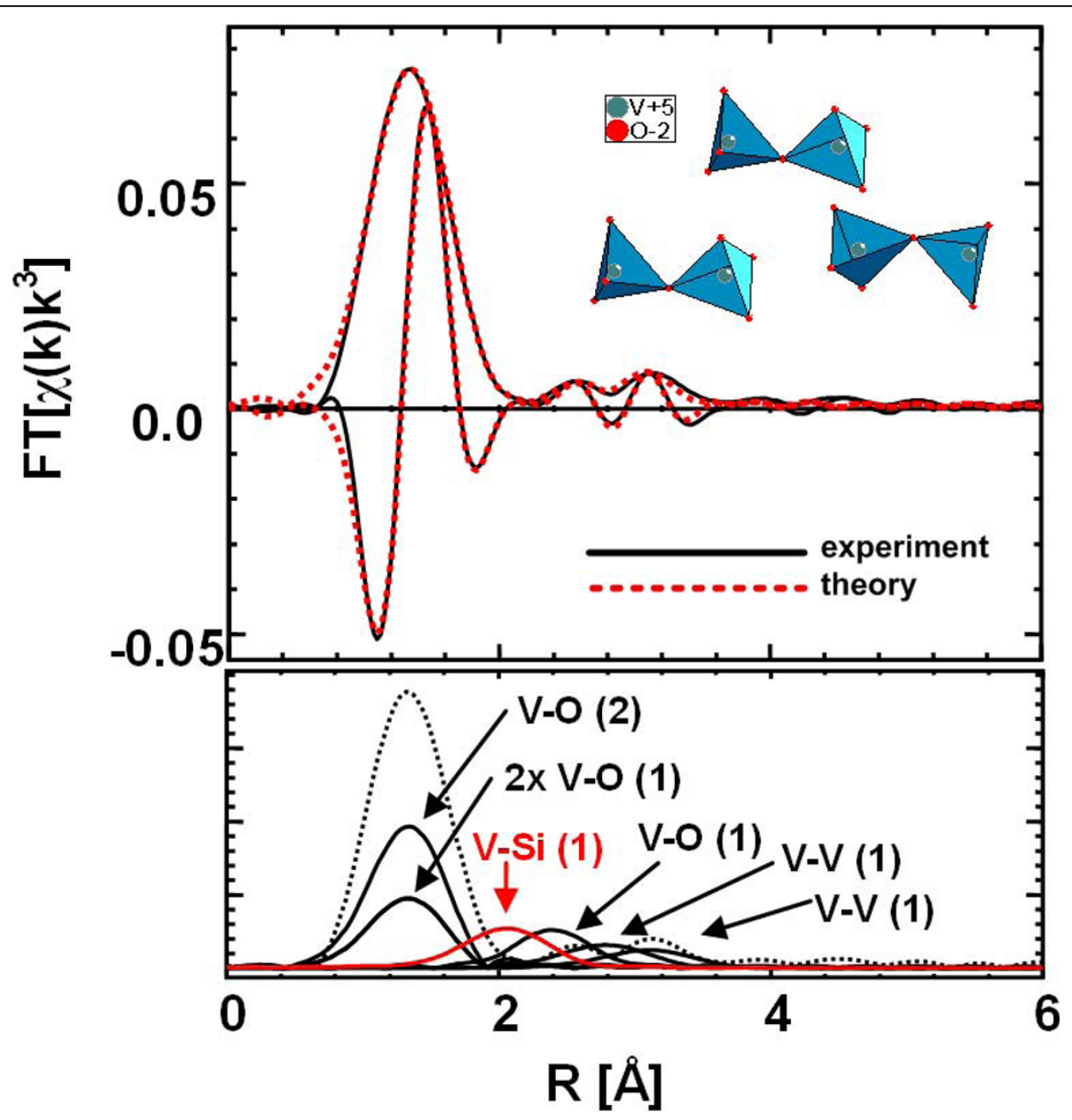

Figure 7 Experimental (solid) $V \mathrm{~K}$ edge $\mathrm{FT}\left(\chi(k)^{*} \mathrm{k}^{3}\right)$ of dehydrated $\mathrm{V}_{\mathrm{x}} \mathrm{O}_{\mathrm{y}} / \mathrm{SBA}-15$ (10.8 wt \%) together with a theoretical XAFS function (i.e. "ordered arrangement of $\mathbf{V}_{\mathbf{2}} \mathbf{O}_{\mathbf{7}}$ " model). Fitting results are given in Table 2. Inset shows a schematic representation of arrangement of $\mathrm{V}_{2} \mathrm{O}_{7}$ units in $\mathrm{Mg}_{2} \mathrm{~V}_{2} \mathrm{O}_{7}$. Also shown are the Fourier transformed $\chi(\mathrm{k})^{*} \mathrm{k}^{3}$ of the individual scattering paths together with corresponding coordination number in brackets.

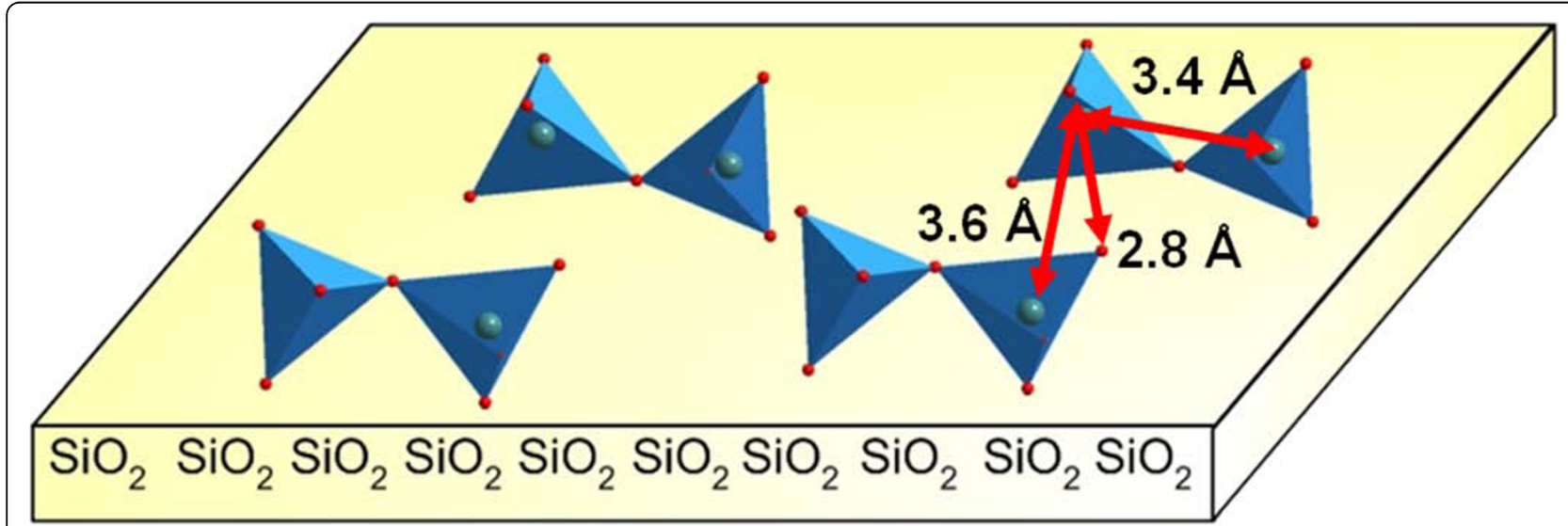

Figure 8 Schematic structural representation of dehydrated $\mathbf{V}_{\mathbf{x}} \mathrm{O}_{\mathbf{y}} / \mathrm{SBA}-\mathbf{1 5}$. The most prominent distances employed in the XAFS refinement procedure are indicated. 


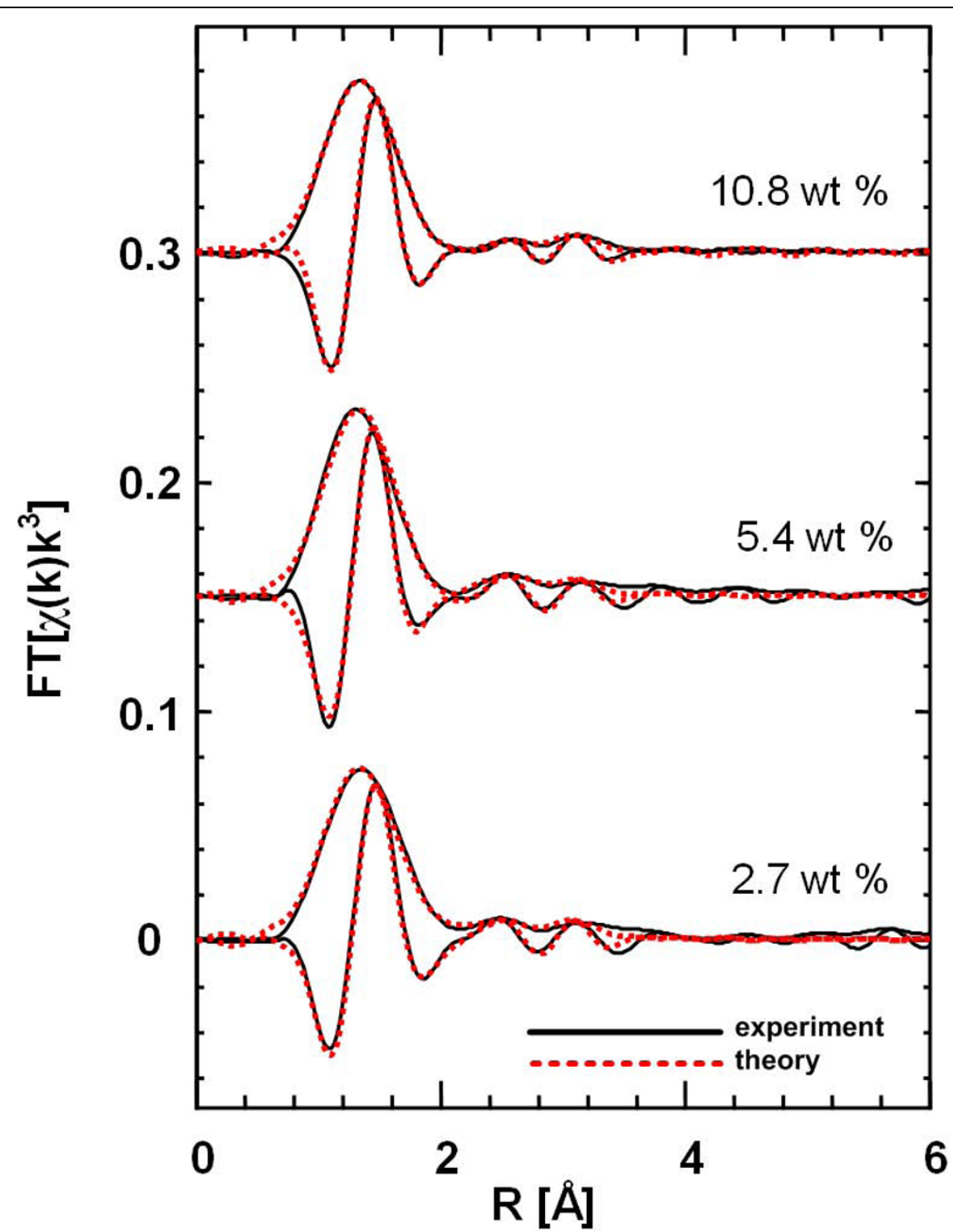

Figure 9 Experimental (solid) $\mathrm{V} \mathrm{K}$ edge $\mathrm{FT}\left(\chi(\mathbf{k})^{*} \mathrm{k}^{3}\right)$ of dehydrated $\mathrm{V}_{\mathrm{x}} \mathrm{O}_{\mathrm{y}} / \mathrm{SBA}-15(2.7 \mathrm{wt} \%, 5.4$ wt \%, and 10.8 wt $\%)$ together with a theoretical XAFS function (structural model depicted in Figure 7). Fitting results are given in Table 4.

Table 4 EXAFS refinement results obtained for different $V$ loadings on $\mathrm{V}_{\mathrm{x}} \mathrm{O}_{\mathrm{y}} / \mathrm{SBA}-15$ in the dehydrated state.

\begin{tabular}{|c|c|c|c|c|c|c|c|c|}
\hline Type & $\begin{array}{l}\text { Model } \\
\mathrm{N}\end{array}$ & $\mathrm{R}[\AA \AA]$ & $\begin{array}{l}10.8 \mathrm{wt} \% \\
\mathrm{R}[\mathrm{A}]\end{array}$ & $\sigma^{2}\left[\AA^{2}\right]$ & $\begin{array}{l}5.4 \mathrm{wt} \% \\
\mathrm{R}[\AA \AA \mathrm{A}]\end{array}$ & $\sigma^{2}\left[\AA^{2}\right]$ & $\begin{array}{l}2.7 \mathrm{wt} \% \\
\mathrm{R}[\AA \AA \mathrm{A}]\end{array}$ & $\sigma^{2}\left[\AA^{2}\right]$ \\
\hline $\mathrm{V}-\mathrm{O}$ & 1 & 1.63 & 1.78 & 0.0075 & 1.77 & 0.0069 & 1.78 & 0.0075 \\
\hline V-O & 1 & 1.70 & 1.78 & 0.0075 & 1.77 & 0.0069 & 1.78 & 0.0075 \\
\hline $\mathrm{V}-\mathrm{O}$ & 2 & 1.76 & 1.78 & 0.0075 & 1.77 & 0.0069 & 1.78 & 0.0075 \\
\hline$V-V$ & 1 & 3.36 & 3.30 & 0.0135 & 3.33 & 0.0114 & 3.37 & 0.0113 \\
\hline $\mathrm{V}-\mathrm{O}$ & 1 & 2.87 & 2.90 & 0.0017 & 2.87 & 0.0022 & 2.86 & 0.0015 \\
\hline$V-V$ & 1 & 3.62 & 3.62 & 0.0135 & 3.62 & 0.0114 & 3.65 & 0.0113 \\
\hline V-Si & 1 & 2.80 & 2.54 & 0.0121 & 2.53 & 0.0139 & 2.54 & 0.0081 \\
\hline
\end{tabular}

Type and number $(\mathrm{N})$ of atoms at distance $\mathrm{R}$ from the absorbing $\mathrm{V}$ atom in a model system assuming an ordered arrangement of $\mathrm{V}_{2} \mathrm{O}_{7}$ units (Figure 7 ) compared to experimental distances and XAFS disorder parameter $\left(\sigma^{2}\right)$. Parameters were obtained from the refinement of this model structure to the experimental $\mathrm{V} \mathrm{K}$ edge XAFS FT $\left(\chi(k){ }^{*} k^{3}\right)$ of dehydrated $\mathrm{V}_{x} \mathrm{O}_{y} / \mathrm{SBA}-15$ with different $\mathrm{V}$ loadings (i.e. $10.8 \mathrm{wt} \%, 5.4 \mathrm{wt} \%, 2.7 \mathrm{wt} \%$ ) (Figure 9) (k range from 2.7-11.0 $\AA^{-1}, \mathrm{R}$ range $0.8-$ $4.0 \AA, \mathrm{N}_{\text {ind }}=18, \mathrm{~N}_{\text {free }}=9, \mathrm{E}_{0}=0 \mathrm{eV}$ in all cases, fit residual $3.6(10.8 \mathrm{wt} \%), 7.0(5.4 \mathrm{wt} \%), 7.8(2.7 \mathrm{wt} \%)$ ) (Subscript $\mathrm{C}$ indicates parameters that were correlated in the refinement). Confidence limits and significance of fitting parameters correspond to those given in for the $10.8 \mathrm{wt} \%$ sample. 
V-Si scattering path was included in the refinement of the "neighboring $\mathrm{V}_{2} \mathrm{O}_{7}$ " model described above (Figure $7)$. The structural parameters and refinement details are given in Table 2 and Table 4. Comparing fit residuals, confidence limits, and $\mathrm{F}$ parameters a significant improvement was visible. Apparently, both local structure in $\mathrm{V}_{\mathrm{x}} \mathrm{O}_{\mathrm{y}}$ species and interaction with $\mathrm{SiO}_{2}$ support are required to describe the $\mathrm{FT}\left(\chi(\mathrm{k}) * \mathrm{k}^{3}\right)$ of dehydrated $\mathrm{V}_{\mathrm{x}} \mathrm{O}_{\mathrm{y}} / \mathrm{SBA}-15$ samples.

\section{Limitations of XAFS analysis of dehydrated $\mathrm{V}_{\mathrm{x}} \mathrm{O}_{\mathrm{y}} / \mathrm{SBA}-15$}

Eventually, the limitations of the XAFS analysis of dehydrated $\mathrm{V}_{\mathrm{x}} \mathrm{O}_{\mathrm{y}} / \mathrm{SBA}-15$ presented here should be discussed. XAFS is not a very sensitive technique with respect to distinguishing and identifying additional minority species. Experimental XAFS spectra are clearly dominated by the signal of the majority phase. Hence, the presence of minority vanadium oxide species in dehydrated $\mathrm{V}_{\mathrm{x}} \mathrm{O}_{\mathrm{y}} / \mathrm{SBA}-15$ with concentrations of less than $\sim 5 \%$ cannot be excluded. Only if the contribution of additional phases amounts to more than $\sim 5-10 \%$, distortion of the $\operatorname{FT}\left(\chi(k)^{*} k^{3}\right)$ and deviation from the model structure assumed will be detectable. This holds in particular, if these minority species happen to be less ordered than the majority phase.

Moreover, XAFS is an averaging technique. Certainly, higher shells should be properly taken into account and various references should be measured for comparison. Even then, however, it may remain difficult to unambiguously distinguish between mixtures of various species or structures. Hence, alternative scenarios with different vanadium oxide species need to be considered and discussed. An equal mixture of isolated $\mathrm{VO}_{4}$ and neighboring $\mathrm{V}_{2} \mathrm{O}_{7}$ units, for instance, may exhibit a XAFS FT $\left(\chi(k)^{*} k^{3}\right)$ similar to that presented here. For two reasons this assumption is not very likely. First, the $\mathrm{V}-\mathrm{O}$ distances in the first " $\mathrm{VO}_{4}$ " shell of the two species would have to be the same. Otherwise a strong reduction in amplitude of the first V-O peak in the $\mathrm{FT}(\chi(\mathrm{k})$ ${ }^{*} k^{3}$ ) caused by destructive interference would be discernible. Second, isolated $\mathrm{VO}_{4}$ would not contribute to the $\mathrm{FT}\left(\chi(\mathrm{k}){ }^{*} \mathrm{k}^{3}\right)$ in the range from $2 \AA$ to $4 \AA$. Thus, reduction in amplitude and much higher $\sigma^{2}$ parameters compared to reference $\mathrm{Mg}_{2} \mathrm{~V}_{2} \mathrm{O}_{7}$ would be detectable. Both are not observed in the EXAFS analysis of dehydrated $\mathrm{V}_{\mathrm{x}} \mathrm{O}_{\mathrm{y}} / \mathrm{SBA}-15$ presented here (Figure 3(b), Table 2). A similar statement holds for isolated $\mathrm{V}_{2} \mathrm{O}_{7}$ units or a less ordered arrangement of neighboring $\mathrm{V}_{2} \mathrm{O}_{7}$ units. Both would result in a reduction in $\mathrm{FT}\left(\chi(\mathrm{k}) * \mathrm{k}^{3}\right)$ amplitude because of missing contribution in the $2-4 \AA$ range or destructive interference caused by a broadened distribution of distances, respectively. Moreover, for isolated or less ordered $\mathrm{V}_{2} \mathrm{O}_{7}$ units a single $\mathrm{V}-\mathrm{V}$ distance would suffice to describe the experimental XAFS spectrum.
This was also not observed in the XAFS analysis procedure employed. Eventually, higher V-Si distances may have to be considered in addition to a V-Si distance of $\sim 2.5 \AA$ (Table 2). However, a significant contribution of $\mathrm{V}$-Si distances at more $3.0 \AA$ range in the $\mathrm{FT}\left(\chi(\mathrm{k}){ }^{*} \mathrm{k}^{3}\right)$ would require a highly ordered arrangement of $\mathrm{V}_{\mathrm{x}} \mathrm{O}_{\mathrm{y}}$ species on the $\mathrm{SiO}_{2}$ support and a very narrow distance distribution. This seems to be unlikely.

In total, assuming a structural arrangement of vanadium centers in dehydrated $\mathrm{V}_{\mathrm{x}} \mathrm{O}_{\mathrm{y}} / \mathrm{SBA}-15$ that has already been established for reference vanadium oxides (i.e. $\mathrm{Mg}_{2} \mathrm{~V}_{2} \mathrm{O}_{7}$ ) is simple and results in a good agreement with experimental data. More complex and artificially constructed arrangements of $\mathrm{V}_{\mathrm{x}} \mathrm{O}_{\mathrm{y}}$ species supported on $\mathrm{SiO}_{2}$ may be conceivable but appear to be less likely. Both XANES and EXAFS analysis corroborate a local structure around the majority of $\mathrm{V}$ centers in dehydrated $\mathrm{V}_{\mathrm{x}} \mathrm{O}_{\mathrm{y}} / \mathrm{SBA}-15$ similar to the ordered arrangement of neighboring $\mathrm{V}_{2} \mathrm{O}_{7}$ dimers in the structure of $\mathrm{Mg}_{2} \mathrm{~V}_{2} \mathrm{O}_{7}$.

\section{Local structure of hydrated $\mathrm{V}_{\mathrm{x}} \mathrm{O}_{\mathrm{y}} / \mathrm{SBA}-15$ Comparison to $\mathrm{V}$ oxide references}

The EXAFS $\chi(k) * k^{3}$ of hydrated $\mathrm{V}_{\mathrm{x}} \mathrm{O}_{\mathrm{y}} / \mathrm{SBA}-15$ (as-prepared) with different $\mathrm{V}$ loadings are depicted in Figure 10. The usable spectral ranged extended from $2.7 \AA$ through $10.5 \AA$. The V K edge XANES spectra and the $\mathrm{FT}\left(\chi(\mathrm{k}) * \mathrm{k}^{3}\right)$ of hydrated $\mathrm{V}_{\mathrm{x}} \mathrm{O}_{\mathrm{y}} / \mathrm{SBA}-15$ are shown in Figure 11. The Fourier transformed $\chi(\mathrm{k}) * \mathrm{k}^{3}$ and the V K near edge spectra of hydrated $\mathrm{V}_{\mathrm{x}} \mathrm{O}_{\mathrm{y}} / \mathrm{SBA}-15$ are compared to those of vanadium oxide references in Figure 12. The XANES spectrum of hydrated $\mathrm{V}_{\mathrm{x}} \mathrm{O}_{\mathrm{y}} / \mathrm{SBA}-15$ resembles that of $\mathrm{MgV}_{2} \mathrm{O}_{6},\left[\mathrm{H}_{3} \mathrm{~N}\left(\mathrm{CH}_{2}\right)_{4}\right]_{6} \mathrm{~V}_{10} \mathrm{O}_{28}$, and $\mathrm{V}_{2} \mathrm{O}_{5}$ (Figure 12(a)). In these vanadium oxide references vanadium centers exhibit a distorted octahedral or distorted square pyramidal coordination. The XANES spectra of hydrated $\mathrm{V}_{\mathrm{x}} \mathrm{O}_{\mathrm{y}} / \mathrm{SBA}-15, \mathrm{~V}_{2} \mathrm{O}_{5}, \mathrm{MgV}_{2} \mathrm{O}_{6}$, and $\left[\mathrm{H}_{3} \mathrm{~N}\right.$ $\left.\left(\mathrm{CH}_{2}\right)_{4}\right]_{6} \mathrm{~V}_{10} \mathrm{O}_{28}$ show a similar height of the pre-edge peak. Because the pre-edge peak height is determined by the coordination of the vanadium centers [29], hydrated $\mathrm{V}_{\mathrm{x}} \mathrm{O}_{\mathrm{y}} / \mathrm{SBA}-15$ also appears to exhibit a distorted square pyramidal coordination of $\mathrm{V}$ centers. This has also been observed by Bell et al. [18] and others.

The range of potential model structures describing the local structure of hydrated $\mathrm{V}_{\mathrm{x}} \mathrm{O}_{\mathrm{y}} / \mathrm{SBA}-15$ can be further narrowed when comparing the corresponding $\mathrm{FT}(\chi(\mathrm{k})$ ${ }^{*} \mathrm{k}^{3}$ ) (Figure 12(b)). Considering peak positions and relative peak heights in the $\mathrm{FT}\left(\chi(\mathrm{k})^{*} \mathrm{k}^{3}\right)$, it appears that from the references available the $\mathrm{FT}\left(\chi(\mathrm{k})^{*} \mathrm{k}^{3}\right)$ of $\mathrm{V}_{2} \mathrm{O}_{5}$ resembles that of hydrated $\mathrm{V}_{\mathrm{x}} \mathrm{O}_{\mathrm{y}} / \mathrm{SBA}-15$. Because of the lower intensity in the $\mathrm{FT}\left(\chi(\mathrm{k})^{*} \mathrm{k}^{3}\right)$ hydrated $\mathrm{V}_{\mathrm{x}} \mathrm{O}_{\mathrm{y}} / \mathrm{SBA}$ 15 may possess a more disordered structure compared to that of crystalline $\mathrm{V}_{2} \mathrm{O}_{5}$. This is in good agreement with a detailed comparison of the corresponding 


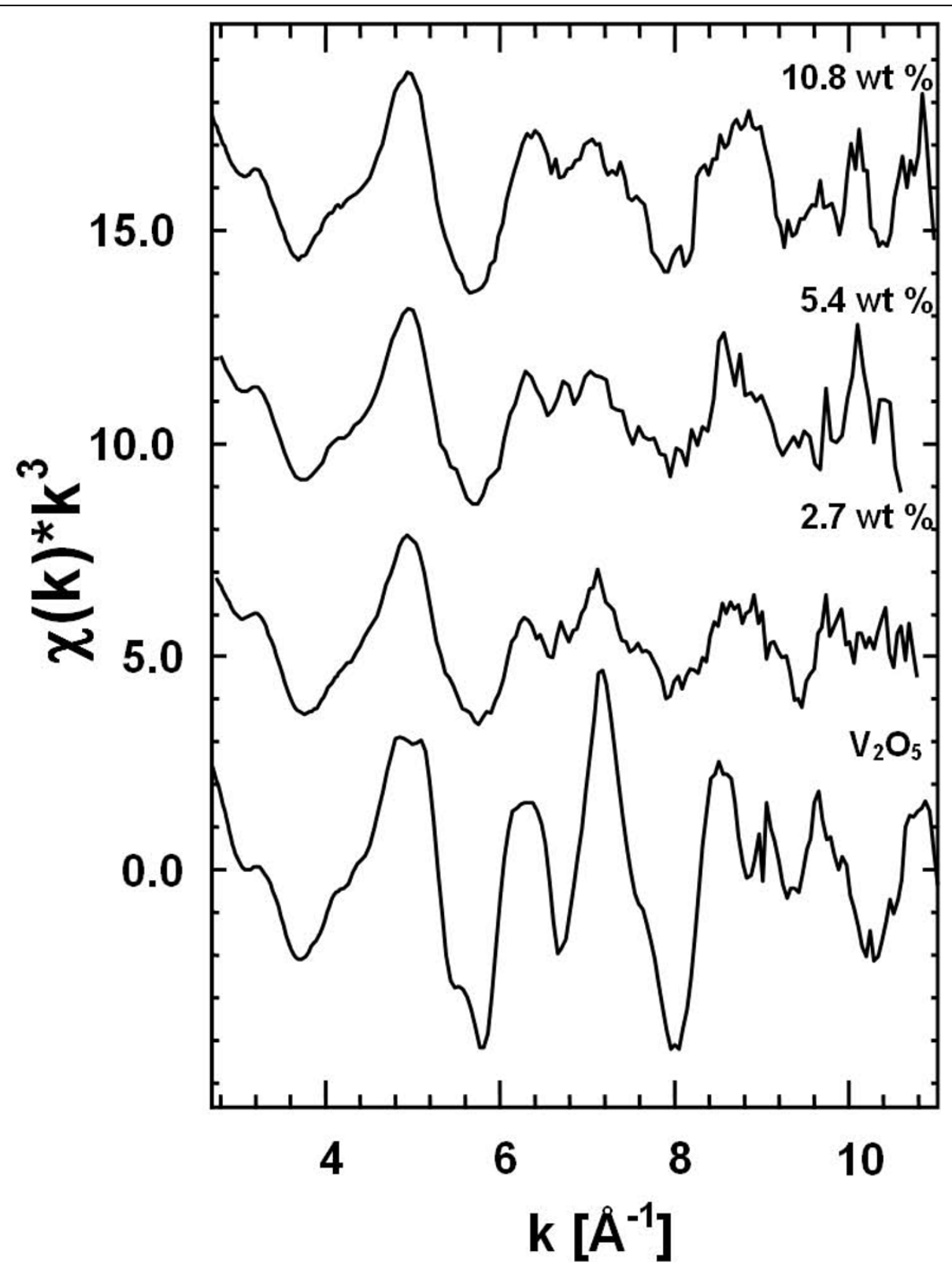

Figure $10 \mathrm{~V} K$ edge $\chi(k)$ of hydrated $\mathrm{V}_{\mathrm{x}} \mathrm{O}_{\mathrm{y}} / \mathrm{SBA}-15$ samples with different vanadium loadings $(2.7 \mathrm{wt} \%, 5.4$ wt $\%$, and 10.8 wt \%) and reference $\mathrm{V}_{2} \mathrm{O}_{5}$.

XANES spectra. On the one hand, the positions of the various peaks in the XANES of hydrated $\mathrm{V}_{\mathrm{x}} \mathrm{O}_{\mathrm{y}} / \mathrm{SBA}-15$ are similar to that of $\mathrm{V}_{2} \mathrm{O}_{5}$ (Figure 12(a)). On the other hand, the lower peak intensities are also indicative of a disordered $\mathrm{V}_{2} \mathrm{O}_{5}$ like structure of the vanadium oxide species in hydrated $\mathrm{V}_{\mathrm{x}} \mathrm{O}_{\mathrm{y}} / \mathrm{SBA}-15$.

Local structure of hydrated $\mathrm{V}_{\mathrm{x}} \mathrm{O}_{\mathrm{y}} / \mathrm{SBA}-15$ XAFS refinement of " $\mathrm{V}_{2} \mathrm{O}_{5}$ " based model structure

Comparison of the XANES and FT $\left(\chi(k) * k^{3}\right)$ of hydrated $\mathrm{V}_{\mathrm{x}} \mathrm{O}_{\mathrm{y}} / \mathrm{SBA}-15$ to those of various references identified
$\mathrm{V}_{2} \mathrm{O}_{5}$ as most suitable model structure for a detailed EXAFS analysis. Ammonium decavanadate decomposes to $\mathrm{V}_{2} \mathrm{O}_{5}$ during treatment in air at temperatures above $773 \mathrm{~K}$. Calcination of the materials studied here will most likely result in formation of the dehydrated species as described above. Re-hydration upon exposure to ambient conditions resulted in vanadium oxide species supported on SBA-15 with a local structure similar to that of $\mathrm{V}_{2} \mathrm{O}_{5}$. A detailed discussion of the underlying formation mechanisms is beyond the scope of this work. Therefore, a theoretical XAFS function calculated on 


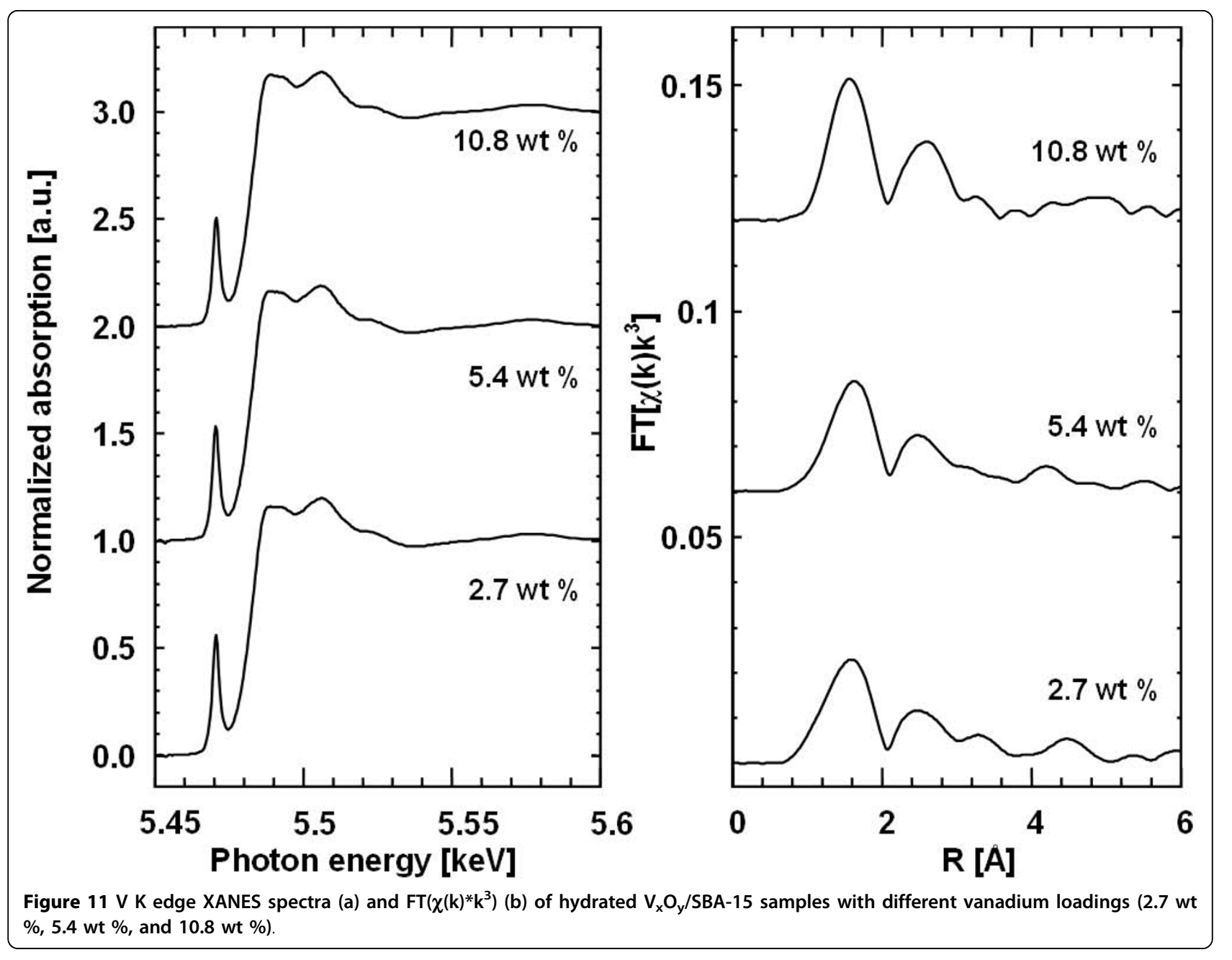

the basis of a $\mathrm{V}_{2} \mathrm{O}_{5}$ model structure (ICSD 60767 [30]) was refined to the experimental $\mathrm{FT}\left(\chi(\mathrm{k}) * \mathrm{k}^{3}\right)$ of hydrated $\mathrm{V}_{\mathrm{x}} \mathrm{O}_{\mathrm{y}} / \mathrm{SBA}-15$. Details of the XAFS refinement procedure and the structural parameters obtained are given in Table 5. In addition, the $\mathrm{V}_{2} \mathrm{O}_{5}$ model structure was refined to the $\mathrm{FT}\left(\chi(\mathrm{k}) * \mathrm{k}^{3}\right)$ of $\mathrm{V}_{2} \mathrm{O}_{5}$ to validate the procedure chosen. Good agreement between the theoretical XAFS function of a $\mathrm{V}_{2} \mathrm{O}_{5}$ model structure and the $\mathrm{FT}(\chi$ $(\mathrm{k})^{*} \mathrm{k}^{3}$ ) of hydrated $\mathrm{V}_{\mathrm{x}} \mathrm{O}_{\mathrm{y}} / \mathrm{SBA}-15$ and $\mathrm{V}_{2} \mathrm{O}_{5}$ was obtained (Figure 13).

As described above, the validity of the XAFS analysis approach chosen was evaluated by calculating confidence limits and F parameters (Table 5). The model structure employed corresponds to the local structure around $\mathrm{V}$ centers in bulk $\mathrm{V}_{2} \mathrm{O}_{5}$ (Table 6). In fitting procedure \#1 there V-O distances $(1.6 \AA, 1.8 \AA$, and $2.0 \AA)$ and two $\sigma^{2}$ (one for $\mathrm{R}=1.6 \AA$ and one for all other $\mathrm{V}$ $\mathrm{O}$ distances) in the first $\mathrm{V}-\mathrm{O}$ shell were allowed to vary independently. Additionally, three $\mathrm{V}-\mathrm{V}$ distances $(3.1 \AA$, 3.4 $\AA$, and $3.6 \AA$ ) with the same $\sigma^{2}$ were refined. Moreover, $E_{0}$ was also allowed to vary in fitting procedure \#1.
Again because of $\mathrm{N}_{\text {ind }}=18$ and $\mathrm{N}_{\text {free }}=10$ refinement procedure \#1 would be considered reliable according to the Nyquist criteria. Reasonable confidence limits and $\mathrm{F}$ $=0$ were calculated for the $\mathrm{V}-\mathrm{V}$ distances and $\sigma^{2}(\mathrm{~V}-\mathrm{V})$ parameter. However, rather high confidence limits of the $\mathrm{V}-\mathrm{O}$ distances of $\pm 0.05 \AA$ and $\mathrm{F}$ parameters of 0.8 for both $\sigma^{2}(\mathrm{~V}-\mathrm{O})$ parameters were obtained with procedure \#1. Moreover, $\mathrm{E}_{0}$ exhibited a confidence limit of \pm 17.0 and $\mathrm{F}=0.9$. Hence, fitting procedure \#1 clearly exceeds the number of meaningful parameters. Therefore, the fitting procedure was modified and the number of free parameters was reduced. $\mathrm{E}_{0}$ was kept invariant again in the refinement, two V-O distances at $\sim 1.6 \AA$ and $1.9 \AA$, and one $\sigma^{2}(\mathrm{~V}-\mathrm{O})$ parameter were used. In contrast to procedure \#1, procedure \#2 yielded reasonable confidence limits (e.g. \pm 0.02 for $\mathrm{V}$-O distances) and acceptable $\mathrm{F}$ parameters (mostly $\mathrm{F}=0$ ).

Table 5 indicates a small increase in the various $\mathrm{V}-\mathrm{O}$ and $\mathrm{V}-\mathrm{V}$ distances from $\mathrm{V}_{2} \mathrm{O}_{5}$ to hydrated $\mathrm{V}_{\mathrm{x}} \mathrm{O}_{\mathrm{y}} / \mathrm{SBA}$ 15. Intercalation of water in hydrated $\mathrm{V}_{\mathrm{x}} \mathrm{O}_{\mathrm{y}} / \mathrm{SBA}-15$ may be accompanied by increasing nearest neighbor 


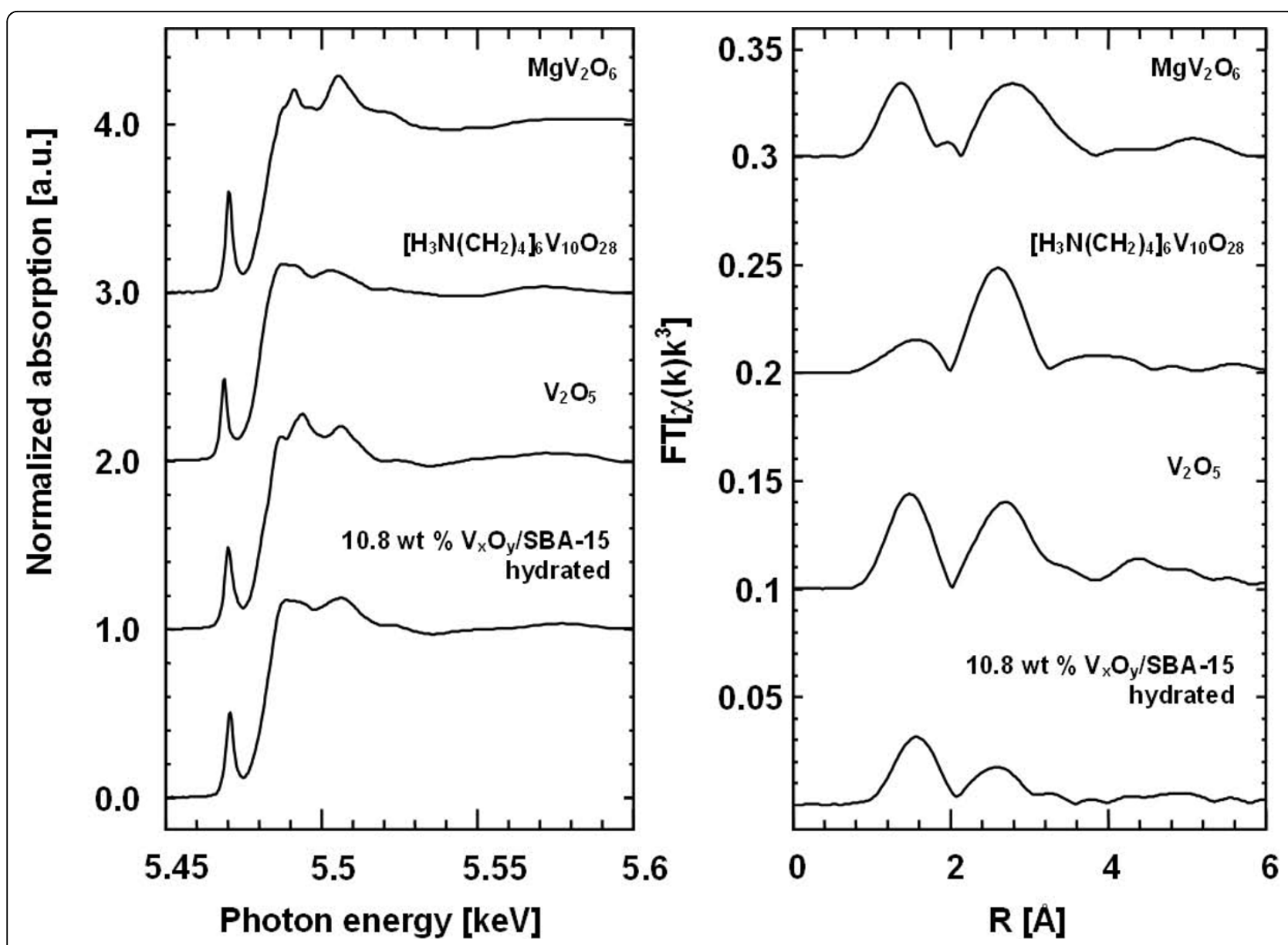

Figure $12 \mathrm{~V} \mathrm{~K}$ edge XANES spectra (a) and $\mathrm{FT}\left(\chi(k) * k^{3}\right)$ of hydrated $\mathrm{V}_{\mathrm{x}} \mathrm{O}_{\mathrm{y}} / \mathrm{SBA}-15$ (10.8 wt \%) compared to those of various references (i.e. $\mathrm{V}_{2} \mathrm{O}_{5},\left[\mathrm{H}_{3} \mathrm{~N}\left(\mathrm{CH}_{2}\right)_{4}\right]_{6} \mathrm{~V}_{10} \mathrm{O}_{28}$, and $\mathrm{MgV}_{2} \mathrm{O}_{6}$ ).

Table 5 Evaluation of EXAFS refinement of dehydrated $\mathrm{V}_{\mathrm{x}} \mathrm{O}_{\mathrm{y}} / \mathrm{SBA}-15$.

\begin{tabular}{|c|c|c|c|c|c|c|c|c|c|c|}
\hline \multirow[b]{2}{*}{ Type } & \multirow[b]{2}{*}{$\mathbf{N}$} & \multicolumn{3}{|c|}{$\mathrm{V}_{2} \mathrm{O}_{5}$, procedure $\# 1$} & \multicolumn{3}{|c|}{$\mathrm{V}_{2} \mathrm{O}_{5}$, procedure \#2 } & \multicolumn{3}{|c|}{ Hydrated $\mathrm{V}_{\mathrm{x}} \mathrm{O}_{\mathrm{y}}-\mathrm{SBA}-15$} \\
\hline & & $\mathrm{Z}$ & $\pm z$ & $\mathbf{F}$ & & & $\mathbf{F}$ & & $\pm z$ & $\mathbf{F}$ \\
\hline$V-O$ & 1 & 1.58 & 0.05 & 0.3 & 1.58 & 0.011 & 0 & 1.65 & 0.014 & 0 \\
\hline$\sigma^{2}(\mathrm{~V}-\mathrm{O})$ & $3(1)$ & 0.011 & 0.0055 & 0.8 & 0.0104 & 0.0069 & 0 & 0.0126 & 0.0003 & 0 \\
\hline$V-O$ & $3(2)$ & 1.87 & 0.06 & 0.3 & 1.88 & 0.014 & & 1.92 & 0.018 & 0 \\
\hline$\sigma^{2}(\mathrm{~V}-\mathrm{O})$ & $-(3)$ & 0.0098 & 0.004 & 0.8 & - & - & - & - & - & - \\
\hline$V-O$ & $-(1)$ & 1.93 & 0.03 & 0.5 & - & - & - & - & - & - \\
\hline$V-V$ & 2 & 3.12 & 0.006 & 0 & 3.11 & 0.003 & 0 & 3.08 & 0.0075 & 0 \\
\hline$\sigma^{2}(V-V)$ & 3 & 0.0047 & 0.00032 & 0 & 0.0047 & 0.00035 & 0 & 0.013 & 0.0006 & 0 \\
\hline$V-V$ & 1 & 3.39 & 0.044 & 0 & 3.38 & 0.046 & 0 & 3.42 & 0.046 & 0.3 \\
\hline$V-V$ & 2 & 3.60 & 0.024 & 0 & 3.59 & 0.024 & 0 & 3.65 & 0.028 & 0 \\
\hline$E_{0}$ & - & 0.38 & 17.0 & 0.9 & - & - & - & - & - & - \\
\hline
\end{tabular}

$\mathrm{V} \mathrm{K}$ edge XAFS parameters ( $\mathrm{Z}$ for distances $\mathrm{R}$ and disorder parameter $\sigma^{2}$ ) obtained from two different procedures of fitting a model structure (i.e. $\mathrm{V}_{2} \mathrm{O}_{5}$ ) to the experimental XAFS FT $\left(\chi(k)^{*} k^{3}\right)$ of reference $\mathrm{V}_{2} \mathrm{O}_{5}$ and hydrated $\mathrm{V}_{\mathrm{x}} \mathrm{O}_{\mathrm{y}} / \mathrm{SBA}-15$ (10.8 wt \%) (details of fit given in Table 6) together with confidence limits $( \pm \mathrm{z}$, referring to $95 \%$ of fit residual) and significance parameter $\mathrm{F}$ (details given in text). Fit residual 6.0 for $\mathrm{V}_{2} \mathrm{O}_{5}$ procedure \#1, 6.3 for $\mathrm{V}_{2} \mathrm{O}_{5}$ procedure \#2, and 13.6 for hydrated $\mathrm{V}_{\mathrm{x}} \mathrm{O}_{\mathrm{y}}-\mathrm{SBA}-15$. 


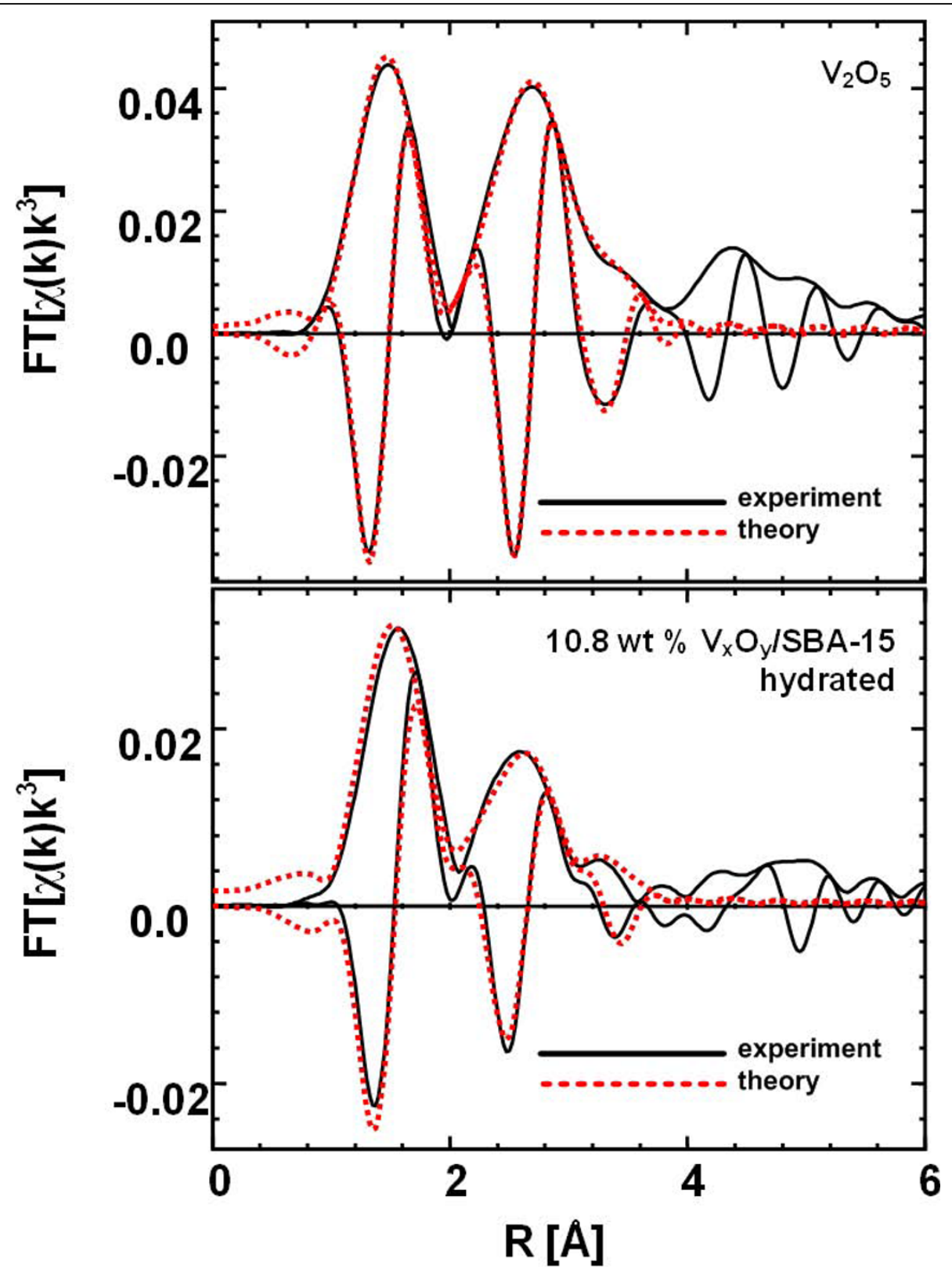

Figure 13 Experimental (solid) $V K$ edge $\mathrm{FT}\left(\chi(k)^{*} k^{3}\right)$ of hydrated $\mathrm{V}_{\mathrm{x}} \mathrm{O}_{\mathrm{y}} / \mathrm{SBA}-15$ (10.8 wt \%) (bottom) and of $\mathrm{V}_{2} \mathrm{O}_{5}$ (top) together with theoretical XAFS functions $\left(\mathrm{V}_{2} \mathrm{O}_{5}\right.$ model).

distances. More pronounced, though, is the increase in the disorder parameter $\sigma^{2}$ for the $\mathrm{V}-\mathrm{O}$ and $\mathrm{V}-\mathrm{V}$ scattering scattering paths used in the XAFS refinement for hydrated $\mathrm{V}_{\mathrm{x}} \mathrm{O}_{\mathrm{y}} / \mathrm{SBA}-15$ (Table 5 ). In particular, $\mathrm{V}-\mathrm{V}$ contributions are strongly damped in the $\mathrm{FT}\left(\chi(\mathrm{k}) * \mathrm{k}^{3}\right)$ of hydrated $\mathrm{V}_{\mathrm{x}} \mathrm{O}_{\mathrm{y}} /$ SBA-15 indicating an increased disorder in the local structure of hydrated $\mathrm{V}_{\mathrm{x}} \mathrm{O}_{\mathrm{y}}$ species supported on SBA-15 compared to bulk $\mathrm{V}_{2} \mathrm{O}_{5}$.

The structural similarity between hydrated vanadium oxide species supported on $\mathrm{SiO}_{2}$ and $\mathrm{V}_{2} \mathrm{O}_{5}$ has previously been observed by Raman spectroscopy [10].
Evidently, the local structure of hydrated $\mathrm{V}_{\mathrm{x}} \mathrm{O}_{\mathrm{y}} / \mathrm{SBA}-15$ used here is very similar to other materials previously described in the literature. Dehydration should therefore result in a similar structure of the dehydrated phase. In addition to $10.8 \mathrm{wt} \% \mathrm{~V}_{\mathrm{x}} \mathrm{O}_{\mathrm{y}} / \mathrm{SBA}-15$, samples with lower loadings of $2.7 \mathrm{wt} \%$ and $5.4 \mathrm{wt} \% \mathrm{~V}$ were measured (Figure 10 and Figure 11) and analyzed according to the procedure described above. Very similar results were obtained for the hydrated state of the low-loading samples compared to 10.8 wt $\%$ hydrated $\mathrm{V}_{\mathrm{x}} \mathrm{O}_{\mathrm{y}} / \mathrm{SBA}-15$. Apparently, in the range of $\mathrm{V}$ loadings from $\sim 3$ to $11 \mathrm{wt}$ 
Table 6 EXAFS refinement results obtained for experimental $\mathrm{FT}\left(\chi(k) * k^{3}\right)$ of hydrated $\mathrm{V}_{\mathrm{x}} \mathrm{O}_{\mathrm{y}} / \mathrm{SBA}-15$ and $\mathrm{V}_{\mathbf{2}} \mathrm{O}_{5}$.

\begin{tabular}{|c|c|c|c|c|c|c|}
\hline \multirow[b]{2}{*}{ Type } & \multicolumn{2}{|c|}{$R_{\text {Model }}[\AA]$} & \multicolumn{2}{|c|}{$\mathrm{V}_{2} \mathrm{O}_{5}$} & \multicolumn{2}{|c|}{ hydrated $\mathrm{V}_{\mathrm{x}} \mathrm{O}_{\mathrm{y}}-\mathrm{SBA}-15$} \\
\hline & $N$ & $R_{\text {Model }}[\AA]$ & $R[\AA ̊]$ & $\sigma^{2}\left[\AA^{2}\right]$ & $R[\AA ̊]$ & $\sigma^{2}\left[\AA^{2}\right]$ \\
\hline $\mathrm{V}-\mathrm{O}$ & 1 & 1.58 & 1.58 & 0.0104 & 1.65 & 0.0126 \\
\hline $\mathrm{V}-\mathrm{O}$ & 1 & 1.78 & 1.88 & $0.0104_{C}$ & 1.92 & $0.0126_{c}$ \\
\hline $\mathrm{V}-\mathrm{O}$ & 2 & 1.88 & $1.88_{C}$ & $0.0104_{C}$ & $1.92_{C}$ & $0.0126_{c}$ \\
\hline$V-O$ & 1 & 2.02 & $1.88_{C}$ & $0.0104_{C}$ & $1.92_{C}$ & $0.0126_{c}$ \\
\hline$V-V$ & 2 & 3.08 & 3.11 & 0.0047 & 3.08 & 0.0129 \\
\hline$V-V$ & 1 & 3.43 & 3.39 & $0.0047_{C}$ & 3.43 & $0.0129 c$ \\
\hline$V-V$ & 2 & 3.56 & 3.59 & $0.0047_{C}$ & 3.65 & $0.0129 c$ \\
\hline
\end{tabular}

Type and number $(\mathrm{N})$ of atoms at distance $\mathrm{R}$ from the $\mathrm{V}$ atoms in a $\mathrm{V}_{2} \mathrm{O}_{5}$ system compared to experimental distances and XAFS disorder parameter $\left(\sigma^{2}\right)$. Parameters were obtained from refinement of a $\mathrm{V}_{2} \mathrm{O}_{5}$ model structure (ICSD 60767) to the experimental $\mathrm{V} K$ edge XAFS FT $\left(\chi(k)^{*} k^{3}\right)$ of hydrated $\mathrm{V}_{\mathrm{x}} \mathrm{O}_{\mathrm{y}} /$ SBA-15 (10.8 wt \%) and bulk $\mathrm{V}_{2} \mathrm{O}_{5}\left(\right.$ ). (k range from 2.7 - $11.0 \AA^{-1}, \mathrm{R}$ range 0.9 $3.8 \AA, \mathrm{E}_{0}\left(\mathrm{~V}_{\mathrm{x}} \mathrm{O}_{\mathrm{y}} / \mathrm{SBA}-15\right)=0.0 \mathrm{eV} / \mathrm{E}_{0}\left(\mathrm{~V}_{2} \mathrm{O}_{5}\right)=0.0$, fit residual $13.4\left(\mathrm{~V}_{\mathrm{x}} \mathrm{O}_{\mathrm{y}} / \mathrm{SBA}-15\right)$ and $6.3\left(\mathrm{~V}_{2} \mathrm{O}_{5}\right), \mathrm{N}_{\text {ind }}=18, \mathrm{~N}_{\text {free }}=7$ ) (Subscript $\mathrm{C}$ indicates parameters that were correlated in the refinement). Confidence limits and significance of fitting parameters are given in Table 5 .

$\%$ the local structure of both hydrated and dehydrated $\mathrm{V}_{\mathrm{x}} \mathrm{O}_{\mathrm{y}} / \mathrm{SBA}-15$ is largely independent of the amount of vanadium oxide supported on SBA-15.

\section{Conclusions}

$\mathrm{X}$-ray absorption spectroscopy is a very suitable technique for studying the local structure of dispersed metals or metal oxides on various support materials. Conventional XAFS analysis consists of finding a suitable model structure and fitting the corresponding theoretical XAFS functions to the experimental data. Because the number of potential parameters often exceeds the number of "independent" parameters, evaluating the reliability and significance of a particular fitting procedure is mandatory. Therefore, the number of independent parameters (Nyquist) alone is not sufficient. Here, we have employed confidence limits and F parameters to identify suitable analysis procedures. The local structure of vanadium oxide supported on nanostructured $\mathrm{SiO}_{2}$ (SBA-15) was investigated. Three samples with different vanadium loadings (i.e. 2.7 wt \%, 5.4 wt \%, and 10.8 wt \%) were employed. Thermal treatment in air at $623 \mathrm{~K}$ resulted in characteristic structural changes of the $\mathrm{V}$ oxide species. The local structure of dehydrated $\mathrm{V}_{\mathrm{x}} \mathrm{O}_{\mathrm{y}} / \mathrm{SBA}-15$ was described best by assuming a model structure consisting of an ordered arrangement of neighboring $\mathrm{V}_{2} \mathrm{O}_{7}$ units. This is in good agreement with recent NEXAFS studies and theoretical calculations that also concluded the presence of $\mathrm{V}-\mathrm{V}$ bonds in the $\mathrm{V}_{\mathrm{x}} \mathrm{O}_{\mathrm{y}}$ species supported on SBA-15 [28]. Moreover, the local structures of both hydrated and dehydrated $\mathrm{V}_{\mathrm{x}} \mathrm{O}_{\mathrm{y}} / \mathrm{SBA}-15$ were found to be independent of the $\mathrm{V}$ loading over the range employed. With respect to XAFS data previously presented in the literature and interpreted in terms of isolated $\mathrm{VO}_{4}$ units it can be suggested that including contributions of higher shells would also lead to conclude polymeric $\mathrm{V}_{\mathrm{x}} \mathrm{O}_{\mathrm{y}}$ units. Comparing the influence of surface properties and structure of various support materials will be the subject of future work. Eventually, onset of catalytic activity in selective propene oxidation was detected at about $573 \mathrm{~K}$. In situ XAS data measured under reaction conditions indicated, that the characteristic ordered arrangement of $\mathrm{V}_{2} \mathrm{O}_{7}$ dimers in the local structure of dehydrated $\mathrm{V}_{\mathrm{x}} \mathrm{O}_{\mathrm{y}} / \mathrm{SBA}-15$ persisted. Future studies on $\mathrm{V}_{\mathrm{x}} \mathrm{O}_{\mathrm{y}}$ species supported on SBA-15 as model systems for vanadium based selective oxidation catalysts will have to take the presence of $\mathrm{V}_{2} \mathrm{O}_{7}$ species rather than isolated $\mathrm{VO}_{4}$ units into account.

\section{Experimental}

\section{Sample preparation}

Silica SBA-15 was prepared according to literature procedures [2]. Details of preparation and characterization of the same catalysts were described elsewhere $[9,10,14]$. Briefly, SBA-15 was functionalized by adding 3-aminopropyltrimethoxysilane (APTMS) to a suspension of SBA-15 in toluene at $338 \mathrm{~K}$. The suspension was stirred for 12 hours. The contents were filtered, washed and finally stirred in $0.3 \mathrm{M} \mathrm{HCl}$ for 12 hours. The contents was filtered again, washed with water and dried in air overnight (functionalized SBA-15). The vanadium oxides supported on SBA-15 were prepared by adding appropriate amounts of butylammonium decavanadate [31] to a suspension of functionalized SBA-15 in water. The resulting powder was calcined at $823 \mathrm{~K}$ for 12 hours. The results of the $\mathrm{N}_{2}$ physisorption analysis of the SBA15 and the SBA- 15 supported vanadium oxide samples are given in and have been discussed in detail previously together with detailed structural characterization [10]. Importantly, in the presence of vanadium oxide the hexagonal structure of SBA-15 is preserved, the mesopores remain accessible to reactants, and the vanadia species are located inside the pores of SBA- 15 .

The vanadium oxides supported on SBA-15 obtained are denoted as hydrated $\mathrm{V}_{\mathrm{x}} \mathrm{O}_{\mathrm{y}} / \mathrm{SBA}-15$ (as-prepared) or dehydrated $\mathrm{V}_{\mathrm{x}} \mathrm{O}_{\mathrm{y}} / \mathrm{SBA}-15$ (after thermal treatment). In addition to $\mathrm{V}_{\mathrm{x}} \mathrm{O}_{\mathrm{y}} / \mathrm{SBA}-15$ several vanadium oxide reference compounds with an average valance of +5 were measured. These were either used as-purchased $\left(\mathrm{V}_{2} \mathrm{O}_{5}\right.$ (Alfa Aesar 99.8\%), $\mathrm{NH}_{4} \mathrm{VO}_{3}$ (Riedel de Haën, 99.5\%) and $\mathrm{Na}_{3} \mathrm{VO}_{4}$ (Alfa Aesar, 99.9\%)) or were prepared according to literature procedures $\left(\mathrm{Mg}_{2} \mathrm{~V}_{2} \mathrm{O}_{7}, \mathrm{MgV}_{2} \mathrm{O}_{6}\right.$, $\mathrm{Mg}_{3} \mathrm{~V}_{2} \mathrm{O}_{8}$ [32], and $\left[\mathrm{H}_{3} \mathrm{~N}\left(\mathrm{CH}_{2}\right)_{4}\right]_{6} \mathrm{~V}_{10} \mathrm{O}_{28}$ [31]).

\section{X-ray absorption spectroscopy (XAS)}

In situ transmission XAS experiments were performed at the V K edge $(5.465 \mathrm{keV})$ at beamline $\mathrm{E} 4$ at the Hamburg Synchrotron Radiation Laboratory, HASYLAB, 
using a $\mathrm{Si}(111)$ double crystal monochromator. The energy range used for $\mathrm{V} K$ near edge scans (XANES) and extended XAFS scans (EXAFS) was 5.4-5.7 keV ( 3 $\mathrm{min} / \mathrm{scan})$ and 5.4-6.0 $\mathrm{keV}(\sim 20 \mathrm{~min} / \mathrm{scan})$, respectively. For in situ and ex situ XAFS measurements samples were mixed with $\mathrm{BN}$ and $\mathrm{PE}$, respectively, and pressed into self-supporting pellets $(5 \mathrm{~mm}$ and $13 \mathrm{~mm}$ in diameter, respectively). In order to obtain an edge jump, $\Delta$ $\mu_{\mathrm{x}}$, at the V K below 1.0, $2 \mathrm{mg}$ of $10.8 \mathrm{wt} \%$ and $5.4 \mathrm{wt}$ $\% \mathrm{~V}_{\mathrm{x}} \mathrm{O}_{\mathrm{y}} /$ SBA-15, $3 \mathrm{mg}$ of 2.7 wt $\% \mathrm{~V}_{\mathrm{x}} \mathrm{O}_{\mathrm{y}} /$ SBA-15, $1 \mathrm{mg}$ for bulk vanadium oxides $\left(\mathrm{NH}_{4} \mathrm{VO}_{3}, \mathrm{~V}_{2} \mathrm{O}_{5},\left[\mathrm{H}_{3} \mathrm{~N}\left(\mathrm{CH}_{2}\right)_{4}\right]\right.$ $\left.{ }_{6} \mathrm{~V}_{10} \mathrm{O}_{28}, \mathrm{Na}_{3} \mathrm{VO}_{4}\right)$ diluted with $\mathrm{BN}(\sim 15 \mathrm{mg})$, and 3-6 $\mathrm{mg}$ for bulk vanadium oxides $\left(\mathrm{Mg}_{3} \mathrm{~V}_{2} \mathrm{O}_{8}, \mathrm{MgV}_{2} \mathrm{O}_{6}\right)$ diluted with PE ( 200 mg) were employed. Transmission XAS measurements were performed in an in situ cell described previously [33]. Dehydration of $\mathrm{V}_{\mathrm{x}} \mathrm{O}_{\mathrm{y}} /$ SBA-15 was conducted in $20 \% \mathrm{O}_{2}$ and $\mathrm{He}$ (total flow 30 $\mathrm{ml} / \mathrm{min}$ ) in a temperature range from $293 \mathrm{~K}$ to $623 \mathrm{~K}$ at a heating rate of $5 \mathrm{~K} / \mathrm{min}$ and a holding time of $30 \mathrm{~min}$ at $623 \mathrm{~K}$. Reaction tests were performed in $5 \%$ propene and $6 \% \mathrm{O}_{2}$ in $\mathrm{He}$ in the temperature range from $293 \mathrm{~K}$ to $723 \mathrm{~K}(5 \mathrm{~K} / \mathrm{min}$, total flow $30 \mathrm{ml} / \mathrm{min})$. The gas atmosphere was analyzed using a noncalibrated mass spectrometer in a multiple ion detection mode (QMS200 from Pfeiffer). Ex situ XAFS measurements were performed in $\mathrm{He}$ atmosphere at room temperature.

$\mathrm{X}$-ray absorption fine structure (XAFS) analysis was performed using the software package WinXAS v3.2 [34]. Background subtraction and normalization were carried out by fitting linear polynomials to the pre-edge and $3^{\text {rd }}$ degree polynomials to the post-edge region of an absorption spectrum, respectively. The extended Xray absorption fine structure (EXAFS) $\chi(\mathrm{k})$ was extracted by using cubic splines to obtain a smooth atomic background $\mu_{0}(\mathrm{k})$. The $\mathrm{FT}\left(\chi(\mathrm{k}){ }^{*} \mathrm{k}^{3}\right)$, often referred to as pseudo radial distribution function, was calculated by Fourier transforming the $\mathrm{k}^{3}$-weighted experimental $\chi(\mathrm{k})$ function, multiplied by a Bessel window, into the R space. EXAFS data analysis was performed using theoretical backscattering phases and amplitudes calculated with the ab-initio multiple-scattering code FEFF7 [35]. EXAFS refinements were performed in $\mathrm{R}$ space simultaneously to magnitude and imaginary part of a Fourier transformed $\mathrm{k}^{3}$-weighted and $\mathrm{k}^{1}$-weighted experimental $\chi(\mathrm{k})$ using the standard EXAFS formula [36]. This procedure strongly reduces the correlation between the various XAFS fitting parameters. Structural parameters allowed to vary in the refinement were (i) disorder parameter $\sigma^{2}$ of selected single-scattering paths assuming a symmetrical pair-distribution function and (ii) distances of selected singlescattering paths. Coordination numbers $(\mathrm{CN}), \mathrm{E}_{0}$ shifts, and amplitude reduction factor $\mathrm{S}_{0}{ }^{2}$ were kept invariant in the final fitting procedures. Correlations of specific parameters to reduce the number of free running parameters and to improve the stability of the refinement are described below.

The statistical significance of the fitting procedure employed was carefully evaluated in three steps. First, the number of independent parameters $\left(\mathrm{N}_{\text {ind }}\right)$ was calculated according to the Nyquist theorem $N_{\text {ind }}=2 / \pi^{*} \Delta R^{*}$ $\Delta \mathrm{k}+2$. In all cases the number of free running parameters in the refinements was well below $\mathrm{N}_{\text {ind }}$. Second, confidence limits were calculated for each individual parameter. In the corresponding procedure, one parameter was successively varied by a certain percentage (i. e. $0.05 \%$ for $\mathrm{R}$ and $5 \%$ for $\sigma^{2}$ ) and the refinement was restarted with this parameter kept invariant. The parameter was repeatedly increased or decreased until the fit residual exceed the original fit residual by more than $5 \%$. Eventually, the confidence limit of the parameter was obtained from linear interpolation between the last and second last increment for an increase in fit residual of $5 \%$. This procedure was consecutively performed for each fitting parameter. Third, a so-called $\mathrm{F}$ test was performed to assess the significance of the effect of additional fitting parameters on the fit residual. The corresponding procedure was adopted from the wellknown library "Numerical Recipes in C" where it is described in detail [37]. In short, one parameter was varied by a certain percentage (i.e. between 2 and $8 \%$ for $R$ and between 10 and $80 \%$ for $\sigma^{2}$ ) and the refinement was restarted with this parameter kept invariant. Subsequently, the difference between experimental and theoretical function (i.e. magnitude and imaginary part of FT $\left(\chi(k)^{*} k^{3}\right)$ for a refinement in $\mathrm{R}$ space) was calculated and compared to that of the original refinement. The corresponding $\mathrm{F}$ parameter ranges between 0.0 and 1.0, where $\mathrm{F}=1.0$ indicates an insignificant change in the fit residual, while $\mathrm{F}=0.0$ indicates a highly significant change in fit residual. The iterative procedure was terminated when the corresponding $\mathrm{F}$ parameter was below 0.7 . Fit parameters with $F=0.8$ or higher are most likely strongly correlated and may be statistically insignificant. These parameters should be kept invariant in the refinement. Eventually, this procedure was also consecutively performed for each fitting parameter.

\section{Acknowledgements}

The Hamburg Synchrotron Radiation Laboratory, HASYLAB, is acknowledged for providing beamtime for this work. This research was supported by the Deutsche Forschungsgemeinschaft (DFG). The authors acknowledge support from the Cluster of Excellence "Unifying Concepts in Catalysis" (DFG). C.H. thanks the DFG for an Emmy Noether fellowship (DFG).

\section{Author details}

'Institut für Chemie, Technische Universität Berlin, Strasse des 17. Juni 135, 10623 Berlin, Germany. ${ }^{2}$ Fritz-Haber-Institute of the Max-Planck-Society, Department of Inorganic Chemistry, Faradayweg 4-6, 14195 Berlin, Germany. 
${ }^{3}$ Eduard-Zintl-Institut für Anorganische und Physikalische Chemie, Technische Universität Darmstadt, Petersenstr. 20, 64287 Darmstadt, Germany.

\section{Authors' contributions}

AW participated in XAFS data measurements and analysis, and drafted the manuscript. RH performed the sample preparation and N2 adsorption analysis. $\mathrm{CH}$ participated in design and coordination of the study, sample preparation, and N2 adsorption analysis. TR participated in XAFS data measurements and analysis, and design and coordination of the study. All authors read and approved the final manuscript.

\section{Competing interests}

The authors declare that they have no competing interests.

Received: 27 October 2009 Accepted: 11 February 2010

Published: 11 February 2010

\section{References}

1. Ressler T, Walter A, Huang ZD, Bensch W: Structure and properties of a supported $\mathrm{MoO}_{3}$-SBA-15 catalyst for selective oxidation of propene. $J$ Catal 2008, 254:170-179.

2. Zhao DY, Huo QS, Feng JL, Chmelka BF, Stucky GD: Nonionic Triblock and Star Diblock Copolymer and Oligomeric Surfactant Syntheses of Highly Ordered, Hydrothermally Stable, Mesoporous Silica Structures. J Am Chem Soc 1998, 120:6024-6036.

3. Hess C: Characterization of the synthesis and reactivity behavior of nanostructured vanadia model catalysts using XPS and vibrational spectroscopy. Surf Sci 2006, 600:3695-3701.

4. Hess C, Drake IJ, Hoefelmeyer JD, Tilley TD, Bell AT: Partial Oxidation of Methanol Over Highly Dispersed Vanadia Supported on Silica SBA-15. Catal Lett 2005, 105:1-8.

5. Liu YM, Cao Y, Yi N, Feng WL, Dai WL, Yan SR, He HY, Fan KN: Vanadium oxide supported on mesoporous SBA-15 as highly selective catalysts in the oxidative dehydrogenation of propane. J Catal 2004, 224:417-428.

6. Liu W, Lai SY, Dai H, Wang S, Sun H, Au CT: Oxidative dehydrogenation of n-butane over mesoporous $\mathrm{VO}_{\mathrm{x}} / \mathrm{SBA}-15$ catalysts. Catal Lett 2007, 113:147-154.

7. Keller DE, Visser T, Soulimani F, Koningsberger DC, Weckhuysen BM: Hydration effects on the molecular structure of silica-supported vanadiumoxide catalysts: A combined IR, Raman, UV-vis and EXAFS study. Vib Spectrosc 2007, 43:140-151.

8. Venkov TV, Hess C, Jentoft FC: Redox Properties of Vanadium lons in SBA15-Supported Vanadium Oxide: An FTIR Spectroscopic Study. Langmuir 2007, 23:1768-1777.

9. Hess C, Wild U, Schlögl R: The mechanism for the controlled synthesis of highly dispersed vanadia supported on silica SBA-15. Microporous and Mesoporous Materials 2006, 95:339-349.

10. Hess C, Tzolova-Müller G, Herbert R: The Influence of Water on the Dispersion of Vanadia Supported on Silica SBA-15: A Combined XPS and Raman Study. J Phys Chem C 2007, 111:9471-9479.

11. Hess C: Direct correlation of the dispersion and structure in vanadium oxide supported on silica SBA-15. J Catal 2007, 248:120-123.

12. Oyama ST, Went GT, Lewis KB, Bell AT, Somorjai GA: Oxygen Chemisorption and Laser Raman Spectroscopy of Unsupported and Silica-Supported Vanadium Oxide Catalysts. J Phys Chem B 1989, 93:6786-6790

13. Gao X, Bare SR, Weckhuysen BM, Wachs IE: In Situ Spectroscopic Investigation of Molecular Structures of Highly Dispersed Vanadium Oxide on Silica under Various Conditions. J Phys Chem B 1998, 102:10842-10852.

14. Hess C, Hoefelmeyer JD, Tilley TD: Spectroscopic Characterization of Highly Dispersed Vanadia Supported on SBA-15. J Phys Chem B 2004, 108:9703-9709

15. Schraml-Marth M, Wokaun A: Spectroscopic Investigation of the Structure of Silica-supported Vanadium Oxide Catalysts at Submonolayer Coverages. J Chem Soc Faraday Trans 1991, 87(16):2635-2646.

16. Gao X, Wachs IE: Investigation of Surface Structures of Supported Vanadium Oxide Catalysts by UV-vis-NIR Diffuse Reflectance Spectroscopy. J Phys Chem B 2000, 104:1261-1268.
17. Bronkema JL, Bell AT: Mechanistic Studies of Methanol Oxidation to Formaldehyde on Isolated Vanadate Sites Supported on MCM-48. J Phys Chem C 2007, 111:420-430.

18. Olthof B, Khodakov A, Bell AT, Iglesia E: Effects of Support Composition and Pretreatment Conditions on the Structure of Vanadia Dispersed on $\mathrm{SiO}_{2}, \mathrm{Al}_{2} \mathrm{O}_{3}, \mathrm{TiO}_{2}, \mathrm{ZrO}_{2}$, and $\mathrm{HfO}_{2}$. J Phys Chem B 2000, 104:1516-1528.

19. Keller DE, Koningsberger DC, Weckhuysen BM: Molecular Structure of a Supported $\mathrm{VO}_{4}$ Cluster and Its Interfacial Geometry as a Function of the $\mathrm{SiO}_{2}, \mathrm{Nb}_{2} \mathrm{O}_{5}$, and $\mathrm{ZrO}_{2}$ Support. J Phys Chem B 2006, 110:14313-14325.

20. Keller $D E$, Koningsberger $D C$, Weckhuysen BM: Elucidation of the molecular structure of hydrated vanadium oxide species by X-ray absorption spectroscopy: correlation between the $\mathrm{V}$... V coordination number and distance and the point of zero charge of the support oxide. Phys Chem Chem Phys 2006, 8:4814-4824.

21. Keller DE, Airaksinen SMK, Krause AO, Koningsberger DC, Weckhuysen BM: Atomic XAFS as a Tool To Probe the Reactivity of Metal Oxide Catalysts: Quantifying Metal Oxide Support Effects. J Am Chem Soc 2007, 129:3189-3197.

22. Keller DE, Weckhuysen BM, Koningsberger DC: Application of AXAFS Spectroscopy to Transition-Metal Oxides: Influence of the Nearest and Next Nearest Neighbour Shells in Vanadium Oxides. Chem-Eur J 2007, 13:5845-5856

23. Weckhuysen BM, Keller DE: Chemistry, spectroscopy and the role of supported vanadium oxides in heterogeneous catalysis. Catal Today 2003, 78:25-46

24. Tanaka T, Yamashita H, Tsuchitani R, Funabiki T, Yoshida S: X-Ray Absorption (EXAFS/XANES) Study of Supported Vanadium Oxide Catalysts. J Chem Soc Faraday Trans 1988, 84(9):2987-2999.

25. Keller DE, de Groot FMF, Koningsberger DC, Weckhuysen BM: ËO ${ }_{4}$ Upside Down: A New Molecular Structure for Supported $\mathrm{VO}_{4}$ Catalysts. J Phys Chem B 2005, 109:10223-10233.

26. Hawthorne $\mathrm{FC}$, Calvo C: The crystal chemistry of the $\mathrm{M}^{+} \mathrm{VO}_{3}\left(\mathrm{M}^{+}=\mathrm{Li}, \mathrm{Na}\right.$, $\mathrm{K}, \mathrm{NH}_{4}, \mathrm{Tl}, \mathrm{Rb}$, and Cs) pyroxenes. J Solid State Chem 1977, 22(2):157-170.

27. Gopal R, Calvo C: Crystal Structure of Magnesium Divanadate, $\mathrm{Mg}_{2} \mathrm{~V}_{2} \mathrm{O}_{7}$. Acta Crystallogr, Sect B 1974, 30(10):B2491-2493.

28. Cavalleri M, Hermann K, Knop-Gericke A, Hävecker M, Herbert R, Hess C, Oestereich A, Döbler J, Schlögl R: Analysis of silica-supported vanadia by $\mathrm{X}$-ray absorption spectroscopy: Combined theoretical and experimental studies. J Catal 2009, 262:215-223.

29. Wong J, Lytle FW, Messmer RP, Maylotte DH: K-edge absorption spectra of selected vanadium compounds. Phys Rev B 1984, 30:5596-5610.

30. Enjalbert $\mathrm{R}$, Galy J: A Refinement of the Structure of $\mathrm{V}_{2} \mathrm{O}_{5}$. Acta Crystallogr, Sect C 1986, C42:1467-1469.

31. Roman P, Aranzabe A, Luque A, Gutierrez-Zorilla JM: Preparation and solid state characterization of some alkylammonium decavanadates. Crystal structure of the hexakis(n-hexylammonium) decavanadate dihydrate. Mater Res Bull 1991, 26:731-740.

32. Gao X, Ruiz P, Xin Q, Guo X, Delmon B: Preparation and characterization of three pure magnesium vanadate phases as catalysts for selective oxidation of propane to propene. Catal Lett 1994, 23:321-337.

33. Ressler T, Jentoft RE, Wienold J, Günter MM, Timpe O: In Situ XAS and XRD Studies on the Formation of Mo Suboxides during Reduction of $\mathrm{MoO}_{3}$. J Phys Chem B 2000, 104:6360-6370.

34. Ressler T: WinXAS: a Program for X-ray Absorption Spectroscopy Data Analysis under MS-Windows. J Synch Rad 1998, 5:118-122.

35. Rehr JJ, Booth $\mathrm{CH}$, Bridges $\mathrm{F}$, Zabinsky SI: X-ray-absorption fine structure in embedded atoms. Phys Rev B 1994, 49:12347-12350.

36. Ressler T, Brock SL, Wong J, Suib SL: Multiple-Scattering EXAFS Analysis of Tetraalkylammonium Manganese Oxide Colloids. J Phys Chem B 1999, 103:6407-6420

37. Teukolsky A, Vetterling WT, Flannery BP: Numerical Recipes: The Art of Scientific Computing Cambridge: Cambridge University Press, Third 2007.

doi:10.1186/1752-153X-4-3

Cite this article as: Walter et al: Structural characterization of vanadium oxide catalysts supported on nanostructured silica SBA-15 using X-ray absorption spectroscopy. Chemistry Central Journal 2010 4:3. 